\title{
Control of Chronic Pain by the Ubiquitin-Proteasome System in the Spinal Cord
}

\author{
Michael H. Ossipov, ${ }^{1}$ Igor Bazov, ${ }^{2}$ Luis R. Gardell, ${ }^{1}$ Justin Kowal, ${ }^{1}$ Tatiana Yakovleva, ${ }^{2}$ Ivan Usynin, ${ }^{2}$ Tomas J. Ekström, ${ }^{2}$ \\ Frank Porreca, ${ }^{1 \star}$ and Georgy Bakalkin ${ }^{2 *}$ \\ ${ }^{1}$ Department of Pharmacology, University of Arizona Health Sciences Center, Tucson, Arizona 85724, and ${ }^{2}$ Department of Clinical Neuroscience, Karolinska \\ Institutet, Stockholm S-17176, Sweden
}

Chronic pain is maintained in part by long-lasting neuroplastic changes in synapses and several proteins critical for synaptic plasticity are degraded by the ubiquitin-proteasome system (UPS). Here, we show that proteasome inhibitors administered intrathecally or subcutaneously prevented the development and reversed nerve injury-induced pain behavior. They also blocked pathological pain induced by sustained administration of morphine or spinal injection of dynorphin A, an endogenous mediator of chronic pain. Proteasome inhibitors blocked mechanical allodynia and thermal hyperalgesia in all three pain models although they did not modify responses to mechanical stimuli, but partially inhibited responses to thermal stimuli in control rats. In the spinal cord, these compounds abolished the enhanced capsaicin-evoked calcitonin gene-related peptide (CGRP) release and dynorphin A upregulation, both elicited by nerve injury. Model experiments demonstrated that the inhibitors may act directly on dynorphin-producing cells, blocking dynorphin secretion. Thus, the effects of proteasome inhibitors on chronic pain were apparently mediated through several cellular mechanisms indispensable for chronic pain, including those of dynorphin A release and postsynaptic actions, and of CGRP secretion. Levels of several UPS proteins were reduced in animals with neuropathic pain, suggesting that UPS downregulation, like effects of proteasome inhibitors, counteracts the development of chronic pain. The inhibitors did not produce marked or disabling motor disturbances at doses that were used to modify chronic pain. These results suggest that the UPS is a critical intracellular regulator of pathological pain, and that UPS-mediated protein degradation is required for maintenance of chronic pain and nociceptive, but not non-nociceptive responses in normal animals.

Key words: proteasome; pain; dynorphin; epoxomicin; plasticity; treatment

\section{Introduction}

One of the most significant public health problems worldwide is the unsatisfactory treatment of chronic pain, and of neuropathic pain in particular (Gureje et al., 1998; Ohayon and Schatzberg, 2003). Neuropathic pain may arise from nerve trauma, disease states, or chemotherapeutic regimens, and is generally considered to be refractory to opioids (Hansson et al., 2001; Nicholson, 2003; Scadding and Koltzenburg, 2005). Persistent exposure to opioids itself can lead to an abnormal enhanced pain state, as shown in preclinical and clinical studies (Guignard et al., 2000; Gardell et al., 2002; Ossipov et al., 2003, 2004; Joly et al., 2005; Angst and Clark, 2006). To understand the mechanisms of en-

\footnotetext{
Received July 7, 2006; revised May 16, 2007; accepted June 3, 2007.

This work was supported by research grants from the Swedish Science Council to G.B., the Swedish AFA Försäkring to T.J.E. and G.B., and National Institutes of Health Grant 5R21DA019465-02 to M.H.0. We thank Dr. J. Miyazaki for MIN6 cells.

*F.P. and G.B. contributed equally to this work.

Correspondence should be addressed to either of the following: Michael H. Ossipov, Department of Pharmacology, College of Medicine, University of Arizona, P.0. Box 245050, Tucson, AZ 85724-5050, E-mail: michaelo@u.arizona.edu; or Georgy Bakalkin, Alcohol and Drug Dependence Research Section, Centrum för Molekylär Medicin L8:01, Department of Clinical Neuroscience, Karolinska Institute, S-171 76Stockholm, Sweden, E-mail: Georgy.Bakalkin@ki.se.

L. R. Gardell's present address: Department of Pharmacology, Cara Therapeutics, 765 Old Saw Mill River Road, Tarrytown, NY 10591.

DOI:10.1523/JNEUROSCI.5126-06.2007

Copyright $\odot 2007$ Society for Neuroscience $\quad$ 0270-6474/07/278226-12\$15.00/0
}

hanced pain, it is essential to identify molecular processes through which pain transmission neurons develop a state of enhanced excitability.

Regulated protein synthesis as well as the selective protein degradation mediated by the ubiquitin-proteasome system (UPS) are two opposing processes that both regulate synaptic plasticity. The UPS functions within synaptic boutons to control the levels of presynaptic proteins (Speese et al., 2003). At the postsynaptic level, the UPS regulates the surface expression and internalization of NMDA- and AMPA-type glutamate receptors (Colledge et al., 2003; Patrick et al., 2003; Moriyoshi et al., 2004). Neuronal activity regulates synaptic composition through the UPS, providing a link between synaptic activity, protein turnover, and the functional reorganization of synapses (Ehlers, 2003). Because of these properties, the UPS may play a role in long-term synaptic modifications characteristic for chronic abnormal pain. Indeed, in a previous study, ionophoretic application of proteasome inhibitors attenuated dorsal horn neuron firing evoked by innocuous and noxious stimuli, and a single intrathecal injection of proteasome inhibitors in rats with chronic constriction sciatic nerve injury (CCI) attenuated hyperalgesia and allodynia (Moss et al., 2002). Based on this report, the present study was undertaken to further characterize the ability of proteasome inhibitors to both prevent and reverse behavioral signs of enhanced abnormal pain. 
We demonstrate here that (1) proteasome inhibitors can both prevent the development of behavioral signs of neuropathic pain and reverse neuropathic pain established after spinal nerve ligation (SNL), and that (2) the effects of the proteasome inhibitor are reversible because chronic pain returns once the inhibitor administration is terminated. We observe that proteasome inhibitors blocked the upregulation of spinal dynorphin and the enhanced capsaicin-evoked release of calcitonin gene-related peptide (CGRP) from primary afferent terminals that are elicited by SNL. Moreover, we demonstrate that proteasome inhibitors abolished enhanced abnormal pain induced by sustained morphine exposure (Guignard et al., 2000; Hansson et al., 2001; Gardell et al., 2002; Nicholson, 2003; Ossipov et al., 2003, 2004; Joly et al., 2005; Angst and Clark, 2006) and by the spinal administration of dynorphin A (Vanderah et al., 1996; Laughlin et al., 1997).

\section{Materials and Methods}

Animal treatments and surgery. Male Sprague Dawley rats (Harlan, Indianapolis, IN) weighing between 225 and $300 \mathrm{~g}$ were maintained in cages in a climate-controlled room on a $12 \mathrm{~h}$ light/dark cycle with ad libitum access to food and water. All testing procedures were performed in accordance with the policies and recommendations of the International Association for the Study of Pain and the National Institutes of Health guidelines for the handling and use of the laboratory animals and were approved by the Institutional Animal Care and Use Committee of the University of Arizona.

Intrathecal catheter placement. Rats were prepared for intrathecal drug injections according to the method described by Yaksh and Rudy (1976) and used routinely in our laboratories (Vanderah et al., 2000). Rats were anesthetized with ketamine/xylazine $(80 \mathrm{mg} / \mathrm{kg} / 20 \mathrm{mg} / \mathrm{kg})$ and the atlanto-occipetal membrane was exposed and punctured. A section of $\mathrm{PE}-10$ tubing $8 \mathrm{~cm}$ in length was passed caudally from the cisterna magna to the lumbar enlargement. The catheter was secured to the musculature, the wound closed, and a $5 \mathrm{~d}$ recovery allowed before any subsequent surgical procedures were performed. Intrathecal injections of epoxomicin were made in a volume of $5 \mu \mathrm{l}$ are followed by a $9 \mu \mathrm{l}$ flush of saline. Progress of the injection is monitored by the movement of a $1 \mu \mathrm{l}$ air bubble placed between drug solution and saline flush.

Drugs and doses. The $\alpha^{1}, \beta^{1}$-epoxy-ketone tetrapeptide epoxomicin (EMD Biosciences, La Jolla, CA) was used because it is the most selective proteasome inhibitor available (Meng et al., 1999; Kisselev and Goldberg, 2001). Epoxomicin preferentially inhibits the rate-limiting chymotrypsin-like catalytic site of the proteasome as well as the trypsinlike and the caspase-like sites, but does not inhibit nonproteasome proteases such as trypsin, chymotrypsin, cathepsin B, papain, or calpain (Meng et al., 1999; Kisselev and Goldberg, 2001). The synthetic tripeptide aldehyde $N$-carbobenzoxyl-Leu-Leu-leucinal (MG132) (Calbiochem) that also demonstrates preferential inhibition of the chymotrypsin-like site, was used because it has the advantage of systemic activity (Tsubuki et al., 1996; Adams et al., 1998; Kisselev and Goldberg, 2001). N-acetyl-LeuLeu-methioninal (ALLM) (Calbiochem) that is structurally similar to MG132, but does not inhibit the proteasome, was used as a control compound. Clasto-lactacystine $\beta$-lactone (Calbiochem), another highly selective nonpeptide nonreversible proteasome inhibitor (Fenteany et al., 1994), was selected to confirm the results obtained with structurally unrelated inhibitor epoxomicin. Epoxomicin was administered in a dose of $0.6 \mathrm{nmol}$ given twice daily at $12 \mathrm{~h}$ intervals. This drug administration protocol was based on the single intrathecal injections reported by Moss and colleagues (2002) and determined by pilot experiments designed to avoid excessive, and potentially toxic, doses. Vehicle for injection of epoxomicin was 5\% DMSO and 95\% saline. MG132 was dissolved in saline and administered twice daily $(5 \mathrm{mg} / \mathrm{kg}$ ) by subcutaneous injection. ALLM and clasto-lactacystine $\beta$-lactone were dissolved in DMSO and used in cellular studies.

$S N L$. Peripheral nerve injury was produced by tight ligation of the $\mathrm{L}_{5}$ and $\mathrm{L}_{6}$ spinal nerves as described by Kim and Chung (1992) and as performed routinely in our laboratories (Malan et al., 2000; Burgess et al., 2002; Gardell et al., 2003a,b). Anesthesia was induced with $2 \%$ halothane in $\mathrm{O}_{2}$ at $21 / \mathrm{min}$ and maintained with $0.5 \%$ halothane in $\mathrm{O}_{2}$. The dorsal vertebral column from $\mathrm{L}_{4}$ to $\mathrm{S}_{2}$ was exposed, and the $\mathrm{L}_{5}$ and $\mathrm{L}_{6}$ spinal nerves of the left hindpaw were identified and carefully isolated. The $\mathrm{L}_{5}$ and $\mathrm{L}_{6}$ spinal nerves were tightly ligated distal to the dorsal root ganglion with a $4-0$ silk suture and the incision was closed. Sham control rats underwent the same surgery and handling as the experimental animals, but without SNL.

Behavioral assays. Responses to noxious thermal stimuli were determined by the hot-plate test. Latency to withdrawal and licking of a hindpaw was determined by placing the animal on a metal plate maintained at $52^{\circ} \mathrm{C}$. Importantly, all rats with nerve injury always responded by lifting and/or licking the hindpaw ipsilateral to the nerve injury whereas animals with sham surgery did not demonstrate any preference in the hindpaw response. The hot-plate latencies of the nerve-injured rats were consistently significantly lower than those of the sham-operated animals. A maximal cutoff of $40 \mathrm{~s}$ prevented tissue damage. Paw withdrawal thresholds to light tactile stimuli were measured by probing the hindpaw with a series of calibrated von Frey filaments $(0.41,0.70,1.20$, 2.00, 3.63, 5.50, 8.5 , and $15 \mathrm{~g}$ ) applied to the plantar aspect of the hindpaw according to the "up-down" method as described previously (Chaplan et al., 1994). Sham-operated rats did not respond to the cutoff filament $(15 \mathrm{~g})$. This strength of tactile stimulus is not considered to be nociceptive (Chaplan et al., 1994). Consequently, it was not possible to quantify a reduced sensitivity, or "hypoesthesia" to non-noxious tactile stimuli. Higher strengths of von Frey filaments had the effect of lifting the animal's hindpaw from the grid, thus necessitating the $15 \mathrm{~g}$ cutoff (Wang et al., 2001; Burgess et al., 2002; Gardell et al., 2002, 2003a,b). Evidence of tactile allodynia was confirmed in rats used for biochemical assessments. Tactile allodynia and thermal hyperalgesia were determined by a significant $(p<0.05)$ reduction in response values from pretreatment baseline values. Antinociception was indicated by a significant increase in hot-plate latency when referenced to the pretreatment values. Motor coordination was determined with the rotarod test (Columbus Instruments, Columbus, OH). The duration of maintaining balance on a rod (7 $\mathrm{cm}$ in diameter) turning at $10 \mathrm{rpm}$ was measured. The cutoff latency was $120 \mathrm{~s}$ (Gardell et al., 2003b). The animals were exposed to the rotarod each day for $3 \mathrm{~d}$ to adapt the rats to the apparatus. The rats were then injected with epoxomicin or MG132 for $7 \mathrm{~d}$ as described above and tested daily on the rotarod for periods of $120 \mathrm{~s}$. Significant loss of motor coordination may be indicative of sedation or of sensory or motor dysfunctions (Gardell et al., 2003b). In addition, the animals were observed for primary overt effects on behavior, such as exploratory behavior, gait, and posture.

CGRP release assay. The evoked release of CGRP was done according to Chen et al. (1996) and as described previously (Gardell et al., 2002, $2003 \mathrm{~b}$ ). The rats were killed by anesthetic overdose $18 \mathrm{~h}$ after the last injection of vehicle or epoxomicin. Minced $(0.2 \mathrm{~mm})$ ipsilateral dorsal quadrant of the lumbar spinal cord (relative to the side of surgery) was superfused at $0.5 \mathrm{ml} / \mathrm{min}$ with oxygenated modified Kreb's buffer $\left(37^{\circ} \mathrm{C}\right.$, $\mathrm{pH}$ 7.4). After $45 \mathrm{~min}$, superfusate was collected in 3 min intervals, 15 min before the addition of capsaicin, for 6 min during infusion of $1 \mu \mathrm{M}$ capsaicin and then for $27 \mathrm{~min}$ afterward. The tubes were preincubated with $100 \mu \mathrm{l}$ of antibody to CGRP (Bachem/Peninsula, Torrance, CA) for $24 \mathrm{~h}$ at $4^{\circ} \mathrm{C}$, mixed with $100 \mu \mathrm{l}$ of $\left[{ }^{125} \mathrm{I}-\mathrm{Tyr} 0\right] \mathrm{CGRP}(28-37)$ and $50 \mu \mathrm{l}$ of goat antiserum to rabbit antibodies, coupled to ferric beads and incubated for $24 \mathrm{~h}$. Bound $\left[{ }^{125} \mathrm{I}\right] \mathrm{CGRP}$ was separated from free tracer through immunomagnetic separation (PerSeptive Diagnostics, Cambridge, MA). Induced release (CGRP level above baseline) was expressed as the percentage of an appropriate within-group control. Data for each fraction were expressed as femtomoles of CGRP per milligram of tissue and evaluated for deviation from normal distribution. We used ANOVA with Fisher's least significant difference test to determine when the level of CGRP release was significantly above basal (unstimulated) levels and, thus, corresponded to induced release. Data were normalized to the appropriate sham-operated control group.

Dynorphin assay. Spinal dynorphin content was measured in the ipsilateral dorsal quadrant of the lumbar enlargement of the spinal cord 
(relative to the side of surgery) as described previously (Wang et al., 2001; Gardell et al., 2002). Spinal tissue was homogenized in $1 \mathrm{~m}$ acetic acid, incubated for $30 \mathrm{~min}$ at $95^{\circ} \mathrm{C}$, and centrifuged at $14,000 \times \mathrm{g}$ for $20 \mathrm{~min}$ at $4^{\circ} \mathrm{C}$. Protein concentrations were determined with the bicinchoninic acid method and immunoassay of rat tissue samples was done using a commercial enzyme immunoassay system for dynorphin $\mathrm{A}(1-17)$ (Bachem/Peninsula). Cell culture medium mixed with acetic acid was run through SP-Sephadex ion exchange C-25 columns and dynorphin A was analyzed by radioimmunoassay (RIA) as described previously (Christensson-Nylander and Terenius, 1985).

Cell cultures. Mouse insulinoma (MIN6) cells (Miyazaki et al., 1990) were cultured in DMEM, $10 \%$ heat-inactivated FBS, $0.1 \%$ $\beta$-mercaptoethanol, and $20 \mathrm{~mm}$ glucose in the presence of proteasome inhibitors or vehicle ( $0.003 \%$ DMSO). To measure secretion, MIN6 cells were incubated in a modified Kreb's-Ringer solution [containing (in mu) $125 \mathrm{NaCl}, 5.9 \mathrm{KCl}, 1.28 \mathrm{CaCl}_{2}, 2.2 \mathrm{MgCl}_{2}, 25 \mathrm{HEPES}, 0.1 \% \mathrm{BSA}, \mathrm{pH}$ 7.4 , and 3 glucose; basal conditions] or in the same buffer with $20 \mathrm{mM} \mathrm{KCl}$ (stimulated conditions) for $20 \mathrm{~min}$ (Zhang et al., 1997). Cell culture medium was mixed with acetic acid ( $1 \mathrm{M}$ final) and analyzed by RIA. MTT colorimetric assay was performed as described previously (Mosmann, 1983).

Cell/tissue extracts. Extraction procedures were performed at $4^{\circ} \mathrm{C}$. Samples of ipsilateral segments of the lumbar spinal cord of the rat (10 samples/group, 40 samples total) or MIN6 cells were homogenized in four volumes of nondenaturing buffer C (20 mM HEPES, pH 7.9, $0.42 \mathrm{M}$ $\mathrm{NaCl}, 25 \%$ glycerol, $1.5 \mathrm{~mm} \mathrm{MgCl} 2,0.4 \mathrm{~mm}$ EDTA, $0.5 \mathrm{~mm}$ DTT, and $0.2 \% \mathrm{NP}-40$ ) supplemented with five times protease (Complete; Roche, Mannheim, Germany) and proteasome (5 $\mu \mathrm{M}$ MG132; Affinity BioReagents, Exeter, UK) inhibitors, centrifuged at 20,000 $\times \mathrm{g}$ for $10 \mathrm{~min}$. Supernatant was kept at $-80^{\circ} \mathrm{C}$ and used for Western blotting or an electromobility shift assay (EMSA). Protein concentration was determined with the Micro BCA TM protein assay (Pierce, Rockford, IL).

Western blotting. Equal amounts of cell/tissue protein extracts were resolved by SDS-PAGE on 10\% Tricine precast gels (Novex, San Diego, CA; Invitrogen, Carlsbad, CA) under reducing condition. Proteins were transferred at $4^{\circ} \mathrm{C}$ onto a nitrocellulose membrane (Schleicher and Schuell, Dassel, Germany) and stained by MemCode Reversible Protein Stain kit (Pierce). Densitometry values of total protein load were used for normalization of Western blot data. Similar results were obtained when $\beta$-tubulin staining was used for normalization. After destaining, membranes were blocked for $30 \mathrm{~min}$ in $5 \%$ nonfat milk, probed with primary antibody to mono-ubiquitin/U5379 (1:100; Sigma, St. Louis, MO), ubiquitin-activating enzyme E1A (1:3000; Affinity BioReagents), $20 \mathrm{~S}$ proteasome subunit $\alpha 7 / \mathrm{HC} 8$ (1:3000; Affinity BioReagents), $\beta$-tubulin 1/SAP.4G5 (1:200,000; Sigma), ubiquitilated proteins/FK2 (1:1000; Affinity BioReagents), synaptophysin/SVP-38 (1:400; Sigma), ubiquitin C-terminal hydrolase L1/PGP9.5 (1:2000; Affinity BioReagents), or rabbit anti-rat prodynorphin (PDYN) antibodies and developed with the ECL detection system (Amersham Biosciences, Little Chalfont, UK). Anti-PDYN antibodies were generated against rat PDYN C-terminal fragment (235-248), conjugated with keyhole limpet hemocyanin via Cys added to their $\mathrm{N}$ terminus, and affinity purified (Yakovleva et al., 2006). Reference samples composed of pooled aliquots of all samples were loaded onto two wells of each gel and their density values were used to assure reproducibility on each blot and interblot comparison. Densitometric analysis was done using Fujifilm (Kanagawa, Japan) Image Gauge software. Samples were analyzed four times.

EMSA. The following oligonucleotides were SDS-PAGE purified and $\left[\mathrm{P}^{32}\right]$ labeled with Klenow enzyme as described previously (Bakalkin et al., 1993). The sequence of the plus strand of wild-type (wt) and mutant (m) $\kappa \mathrm{B}$ fragments of the immunodeficiency virus enhancer is shown; wt and $\mathrm{m}$ $\kappa \mathrm{B}$ sites are underlined and mutated nucleotides are indicated by bold letters: wt $\kappa \mathrm{B}, 5^{\prime}$ - GGTGATCAGGGACTTTCCGCTGGGGACTTTCCAGGAT$3^{\prime} ; \mathrm{m} \kappa \mathrm{B}, 5^{\prime}$ - GGTGATCATTCACTTTCCGCTATTCACTTTCCAGGAT$3^{\prime}$. Minus strands were extended one to three nucleotides from the $5^{\prime}$ end and recessed by one to three nucleotides from the $3^{\prime}$ end.

The EMSA was performed essentially as described previously (Bakalkin et al., 1993). Protein extracts $(10 \mu \mathrm{g})$ in buffer $\mathrm{C}$ were added to the binding mixture (20 $\mu \mathrm{l}$ of $10 \mathrm{~mm}$ Tris- $\mathrm{HCl}, \mathrm{pH} 7.5,20 \mathrm{~mm} \mathrm{KCl}, 1 \mathrm{~mm}$
EDTA, 7.5\% glycerol, $1.5 \mathrm{~mm}$ DTT, $20 \mu \mathrm{g}$ BSA and 40-60,000 cpm $\left[{ }^{32} \mathrm{P}\right]$-labeled oligonucleotide) and incubated for $20-30 \mathrm{~min}$ at room temperature. The reaction mixture was loaded onto a $5 \%$ polyacrylamide gel in $0.5 \times$ TGE ( 25 mм Tris-HCl, 0.19 м glycine, 1 mм EDTA, $\mathrm{pH} 8.5$ ) buffer. In competition experiments, $10 \mathrm{ng}$ of unlabeled wt $\kappa \mathrm{B}$ or $\mathrm{m} \kappa \mathrm{B}$ oligonucleotide were added to the incubation mixture before the initiation of the binding reaction. After electrophoresis, the gels were fixed in $40 \%$ methanol containing 3\% acetic acid for $10 \mathrm{~min}$, dried, and exposed to an intensifying screen. Detection was performed on a PhosphorImager BAS 1500 (Fujifilm) and images were analyzed using Fujifilm Image Gauge software.

$20 S$ proteasome activity assay. MIN6 cells were incubated with $20 \mathrm{~nm}$ epoxomicin or vehicle for $18 \mathrm{~h}$. Cell pellet or rat spinal cord tissues (the ipsilateral lumbar quadrants relative to the side of injury) were sonicated for $1 \mathrm{~min}$ in $10 \%(\mathrm{w} / \mathrm{v})$ ice-cold $50 \mathrm{~mm}$ Tris- $\mathrm{HCl}, \mathrm{pH} 7.5$, containing 1 mM EDTA. Homogenates were aliquoted and kept at $-80^{\circ} \mathrm{C}$. Protein concentration was determined by Lowry assay with BSA as a standard. Chymotrypsin-like activity of proteasome was analyzed with 10 and 50 $\mu \mathrm{g}$ of cell homogenates by monitoring the cleavage of fluorogenic substrate Suc-Leu-Leu-Val-Tyr-7-amino-4-methylcoumarin (Suc-LLVYAMC; Alexis Biochemicals, Lausen, Switzerland) in reaction buffer containing $25 \mathrm{~mm}$ HEPES and $0.5 \mathrm{~mm}$ EDTA, pH 7.6, supplied with $0.03 \%$ SDS and $50 \mu \mathrm{M}$ Suc-LLVY-AMC. Fluorescence intensity was measured using a fluorometric plate reader at $380 \mathrm{~nm}$ exitation wavelength and 460 $\mathrm{nm}$ emission wavelength at $37^{\circ} \mathrm{C}$ for $2 \mathrm{~h}$; the reaction was linear during the time of measurement.

Statistical analysis. Statistical comparisons within treatment groups were done using one- or two-way ANOVA followed by the Fisher's least significant difference test or the Student-Neuman-Keuls post hoc test, and comparisons among treatment groups were made with two-factor ANOVA for independent variables. Paired comparisons were made with Student's $t$ test. Significance was set at $p \leq 0.05$.

Animal studies and CGRP and dynorphin A assays in animal tissues were performed at the Department of Pharmacology, University of Arizona Health Sciences Center (Tucson, AZ). Frozen samples of rat spinal cord were shipped to the Department of Clinical Neuroscience, Karolinska Institutet (Stockholm, Sweden) where other biochemical analyses and cell culture studies were conducted.

\section{Results}

\section{Proteasome inhibitors prevent and reverse neuropathic pain}

Epoxomicin, the most selective and potent proteasome inhibitor that binds covalently to the proteasome, and MG132, which is a more common, systemically active and reversible proteasome inhibitor (Adams et al., 1998; Tsubuki et al., 1996; Meng et al., 1999; Kisselev and Goldberg, 2001; Groll and Huber, 2004), were used for analysis of the effects of proteasome inhibition on chronic pain. Both inhibitors injected separately prevented behavioral neuropathic pain in rats with $\mathrm{L}_{5} / \mathrm{L}_{6} \mathrm{SNL}$ (Fig. 1). The rats received twice-daily spinal injections of epoxomicin ( $0.6 \mathrm{nmol} /$ dose $)$ or systemic injections of MG132 (5 mg/kg, s.c.) or vehicle, beginning on the day of sham or SNL surgery. Paw withdrawal thresholds to light tactile stimuli (von Frey filaments) and hot-plate latencies were monitored daily before the first injection of the day. Rats with SNL and vehicle injections developed tactile allodynia and thermal hyperalgesia, as indicated by significant $\left(F_{(7,32)}=12.61, p=1.23 \times 10^{-7}\right.$ and $F_{(7,77)}=4.646, p=0.0002$ for tactile and thermal stimuli, respectively) reductions in response endpoints when compared with pre-SNL baseline levels. Treatment of SNL rats with spinal epoxomicin (Fig. 1A) or systemic MG132 (Fig. 1C) for $7 \mathrm{~d}$ completely prevented the development of tactile allodynia in rats with SNL. The paw withdrawal thresholds of the rats receiving epoxomicin or MG132 were significantly $\left(F_{(1,80)}=190.61, p=7.13 \times 10^{-23}\right.$ and $F_{(1,80)}=27.511$, $p=0.0000012$ for epoxomicin and MG132, respectively) greater than those of the vehicle-treated SNL groups. Treatment with 


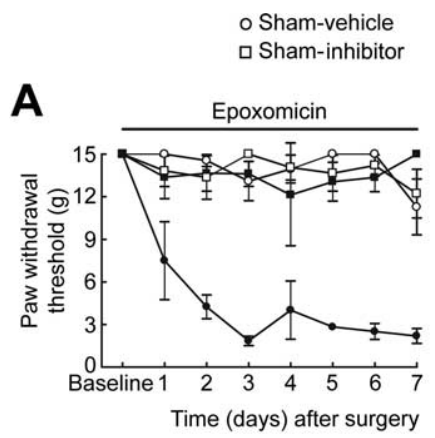

- SNL-vehicle

- SNL-inhibitor

B
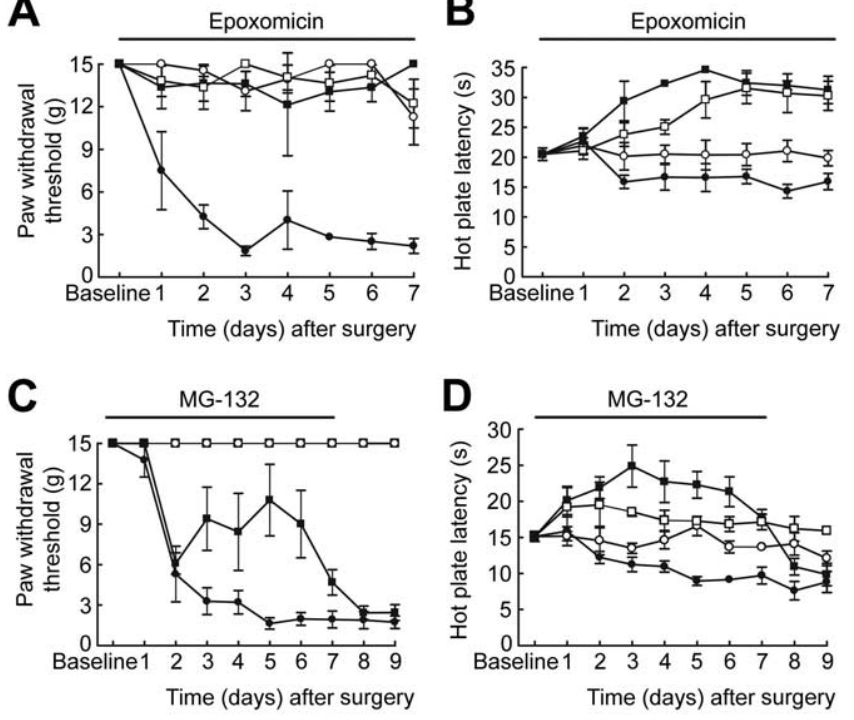

$\mathbf{E}$
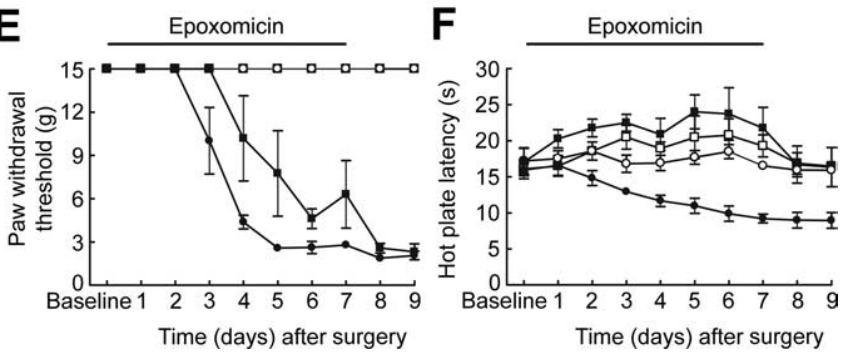

Figure 1. The proteasome inhibitors epoxomicin or MG132 prevent behavioral signs of neuropathic pain in rats with SNL. $\boldsymbol{A}-\boldsymbol{F}$, Responsive thresholds to innocuous mechanical (von Frey filaments; $\boldsymbol{A}, \boldsymbol{C}, \boldsymbol{E})$ and thermal $\left(52^{\circ} \mathrm{C}\right.$ hot-plate) stimuli $(\boldsymbol{B}, \boldsymbol{D}, \boldsymbol{F})$. The rats received twice-daily spinal injections of either epoxomicin at a high $(0.6 \mathrm{nmol} ; \boldsymbol{A}, \boldsymbol{B})$ or low dose $(0.3 \mathrm{nmol} ; \boldsymbol{E}, \boldsymbol{F})$ or vehicle, or received systemic injections of MG132 $(5 \mathrm{mg} / \mathrm{kg}$ per injection, S.C.; $\boldsymbol{C}, \boldsymbol{D})$ beginning on the day of sham or SNL surgery. The top bars indicate the time periods of drug administration. Responses of proteasome-treated animals with SNL were significantly greater than those of vehicle-treated animals with SNL (two-factor ANOVA). SNL produced significant reductions in response parameters in vehicle-treated animals, and after termination of administration of the proteasome inhibitors. Error bars indicate mean \pm SEM. $n=6-7$ per group.

spinal epoxomicin or systemic MG132 prevented the development of thermal hyperalgesia and produced a moderate antinociceptive effect, indicated by significant $\left(F_{(1,80)}=104.29, p=\right.$ $3.74 \times 10^{-16}$ and $F_{(1,104)}=84.91, p=3.81 \times 10^{-15}$ for epoxomicin and MG132, respectively) increases in hot-plate latencies (Fig. $1 B, D)$. Paw withdrawal thresholds in sham-operated rats after treatment with spinal epoxomicin (Fig. 1A) or systemic MG132 (Fig. 1C) were not changed, demonstrating that responses to tactile stimuli were not impaired. Hot-plate latencies in shamoperated rats after systemic MG132 (Fig. 1D) were not changed whereas those after spinal epoxomicin developed a moderate, but significant $\left(F_{(7,37)}=4.602 ; p=0.0008\right)$ increase (Fig. $\left.1 B\right)$. To test whether effects were dose-dependent, we varied doses of epoxomicin, whereas twice-daily spinal injection protocol was not changed throughout the experiments. At a lower dose of $0.3 \mathrm{nmol}$ per injection, epoxomicin partially prevented the development of tactile allodynia and completely prevented the development of thermal hyperalgesia (Fig. 1 E,F). Although the inhibition of tactile allodynia was not as robust as with the higher dose, paw withdrawal thresholds of the epoxomicin-treated group with SNL were significantly $\left(F_{(1,81)}=1.879 ; p=0.000042\right)$ greater
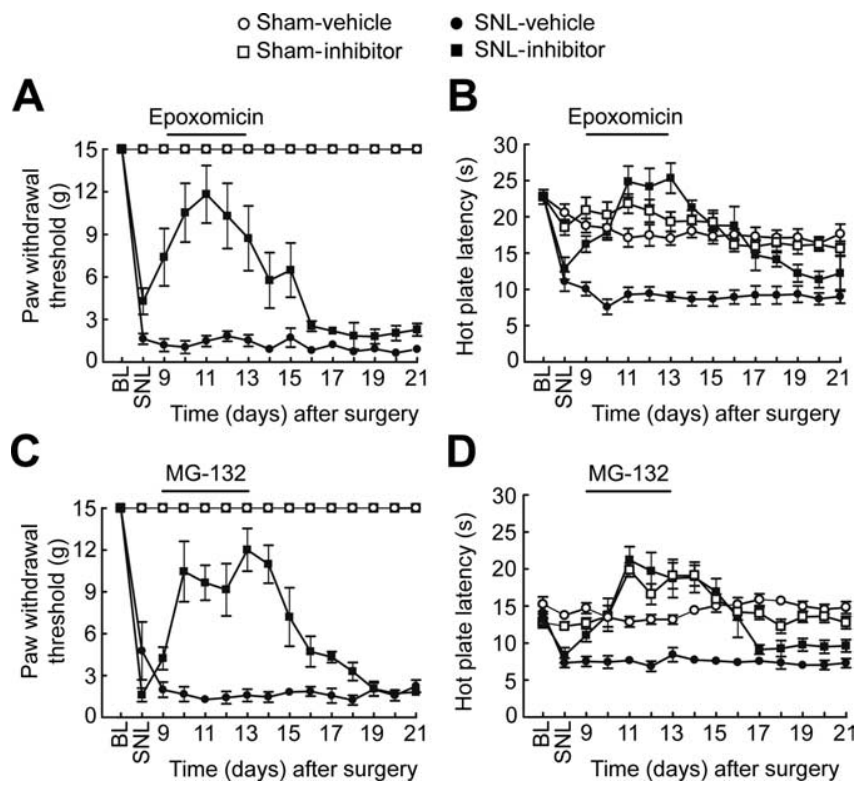

Figure 2. The proteasome inhibitors epoxomicin and MG132 reverse behavioral neuropathic pain in rats with SNL. $A-D$, Responsive thresholds to innocuous mechanical (von Frey filaments; $\boldsymbol{A}, \boldsymbol{C})$ and thermal $\left(52^{\circ} \mathrm{C}\right.$ hot-plate; $\left.\boldsymbol{B}, \boldsymbol{D}\right)$ stimuli. SNL produced significant reductions in paw withdrawal thresholds and hot-plate latencies $8 \mathrm{~d}$ after surgery (SNL; ANOVA). Rats received twice-daily subcutaneous injections of either spinal epoxomicin $(0.6 \mathrm{nmol}$ per injection) or systemic MG132 (5 mg/kg/injection) or vehicle starting on day 9 and finishing on day 13. Paw withdrawal thresholds and hot-plate latencies were monitored daily before the first injection of the day. Treatment with proteasome inhibitors produced significant reversals in the enhanced behavioral responses (two-factor ANOVA) that returned to baseline values after termination of administration of the proteasome inhibitor. The top bars indicate time periods of inhibitor administration. Error bars indicate mean \pm SEM. $n=4-6$ per group.

than those of the vehicle-treated group with SNL. The hot-plate latencies of the group with SNL receiving epoxomicin were significantly $\left(F_{(1,81)}=136.8 ; p=4.43 \times 10^{-19}\right)$ greater than those of the vehicle-treated SNL group. Epoxomicin treatment produced a slight, and nonsignificant, elevation in hot-plate latencies of the sham-operated group (Fig. $1 F)\left(F_{(1,100)}=3.589 ; p=\right.$ 0.061 ), indicating that epoxomicin treatment did not interfere with normal responses to sensory stimuli. Moreover, none of the animals treated with epoxomicin displayed any overt behavioral effects indicative of adverse effects. The repeated spinal administration of $0.07 \mathrm{nmol}$ of epoxomicin per injection did not produce any changes in behavioral signs of hyperalgesia.

We next examined whether proteasome inhibitors could reverse established neuropathic pain (Fig. 2). Once the enhanced responses to tactile and thermal stimuli were firmly established in SNL rats, indicated by significant reductions in paw withdrawal thresholds to tactile stimuli and significant decreases in hot-plate latencies, injections of inhibitors or vehicle were initiated. Animals received either twice-daily spinal injections of epoxomicin (0.6 nmol per dose) or twice-daily subcutaneous injection of MG132 (5 mg/kg per dose) starting from day 9 after SNL or sham surgery. Epoxomicin (Fig. 2A,B) or MG132 (Fig. 2C,D) reversed the tactile allodynia and thermal hyperalgesia in rats with SNL. Paw withdrawal thresholds to light tactile stimuli and hot-plate latencies were significantly $\left(F_{(7,32)}=5.46, p=0.0003\right.$ and $F_{(7,32)}=$ $5.38, p=0.0004$, respectively) elevated when compared with the post-SNL values, indicative of behavioral hyperalgesia, and these values approached the pre-SNL baseline levels. Termination of the epoxomicin or MG132 injections was followed by a reestablishment of tactile allodynia and thermal hyperalgesia, indicating 
reversibility of the effect of proteasome inhibitors. Thus, both spinal and systemic treatment with proteasome inhibitors is effective against behavioral signs of neuropathic pain. Neither epoxomicin nor MG132 produced any changes in paw withdrawal threshold in sham-operated animals; mean withdrawal thresholds remained at $15 \pm 0 \mathrm{~g}$ throughout the study. Both epoxomicin and MG132 produced moderate, reversible, significant $\left(F_{(8,135)}=2.383, p=0.0196\right.$ and $F_{(12,52)}=6.631, p=5.13 \times$ $10^{-7}$ for epoxomicin and MG132, respectively) increases in hotplate latencies in sham-operated rats (Fig. $2 B, D$ ).

\section{Epoxomicin normalizes evoked transmitter release}

Effects of epoxomicin on SNL-induced functional neurochemical alterations were first evaluated by measuring capsaicinevoked release of CGRP, an excitatory peptidic neurotransmitter released from the central terminals of a subclass (peptidergic) of unmyelinated primary afferent nociceptors (Gardell et al., 2003a) from spinal dorsal horn sections obtained ipsilateral to SNL or sham surgery (Fig. 3). Rats with SNL or sham surgery received vehicle or epoxomicin $(0.6 \mathrm{nmol} /$ dose $)$ twice daily for $7 \mathrm{~d}$. No differences in basal release of CGRP were found among the four treatment groups (Fig. 3A). Capsaicin-induced CGRP release from tissues of vehicle-treated SNL rats was significantly elevated compared with that of the vehicle-treated, sham-operated rats (Fig. 3A,B). Epoxomicin treatment significantly reduced capsaicin-evoked CGRP release from tissues of both shamoperated and SNL rats. Thus, epoxomicin prevents the SNLinduced enhancement of capsaicin-evoked release of CGRP.

Epoxomicin normalizes spinal dynorphin A content post-SNL and inhibits dynorphin secretion

SNL induces upregulation of spinal dynorphin A that is critical for the maintenance of neuropathic pain (Gardell et al., 2004; Xu et al., 2004) which does not persist in PDYN knock-out mice (Wang et al., 2001). Consistently, rats with SNL that received vehicle showed an elevation $\left(F_{(3,33)}=4.688 ; p=0.008\right)$ of the dynorphin A content in the dorsal quadrant of the spinal cord ipsilateral to the side of injury compared with the sham-operated, vehicle-treated control group (Fig. $4 A$ ). Epoxomicin administration to SNL rats for $7 \mathrm{~d}$ (twice-daily i.t. injections of $0.6 \mathrm{nmol}$ ) completely normalized the dynorphin A levels.

We next examined whether proteasome inhibitors may target the PDYN system. Mouse insulinoma MIN6 cells that express PDYN, process it to dynorphin peptides, and secrete these peptides through the regulated secretory pathway (Josefsen et al., 1998) were used as a model; no neuronal cells for such analysis are available. Treatment of MIN6 cells with 20 and 200 nM epoxomicin for $16 \mathrm{~h}$ (1) decreased the intracellular levels of PDYN by 40 and $60 \%$, and (2) inhibited secretion of dynorphin $A$ into the medium by 80 and $90 \%$, respectively (Fig. $4 B, C$ ). Incubation of cells with $100 \mathrm{~nm} \mathrm{MG132}$ for $16 \mathrm{~h}$ inhibited secretion of dynorphin A to the medium by $90 \%$ and with $5 \mu \mathrm{M}$ clasto-lactacystine $\beta$-lactone by $67 \%$ (Fig. $4 C$ ). ALLM ( $1 \mu \mathrm{M})$ that has a chemical structure similar to MG132, but does not inhibit the proteasome, failed to affect dynorphin A secretion (Fig. 4C). Data obtained with three proteasome inhibitors of different chemical classes and a control compound suggest that observed effects are caused by inhibition of the proteasome. Secretion of dynorphin A was stimulated 3.7-fold by a $20 \mathrm{~min}$ exposure of cells to $20 \mathrm{~mm}$ potassium concentration compared with incubation at the basal 5.9 mu concentration (Fig. 4D). Preincubation of cells with $100 \mathrm{~nm}$ epoxomicin for $16 \mathrm{~h}$ substantially (2.3-fold) inhibited this stimulation (Fig. 4D). Reduced extracellular levels of dynorphin A

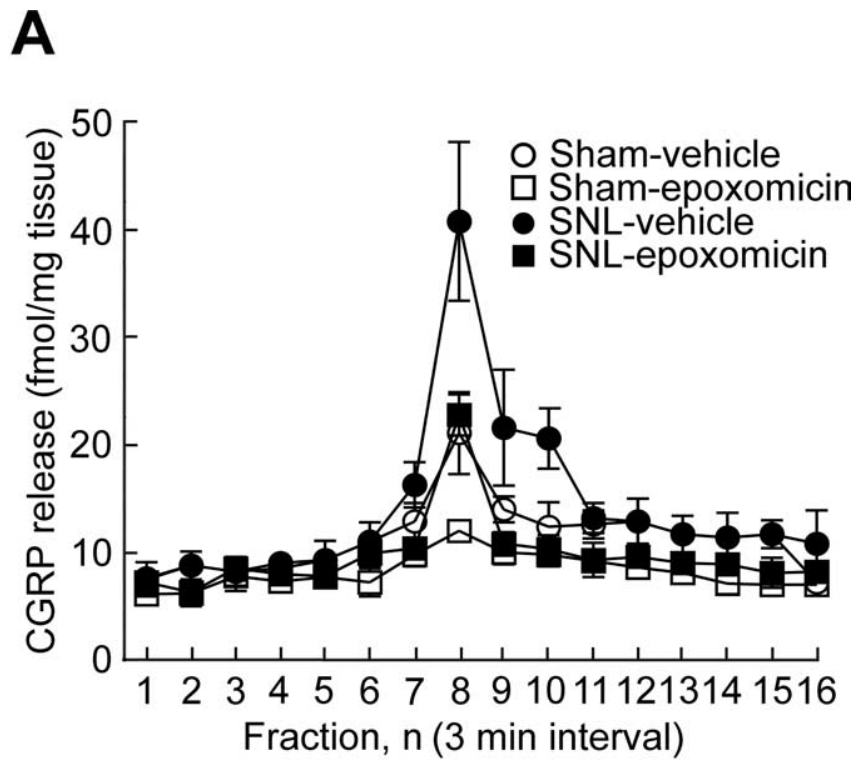

B

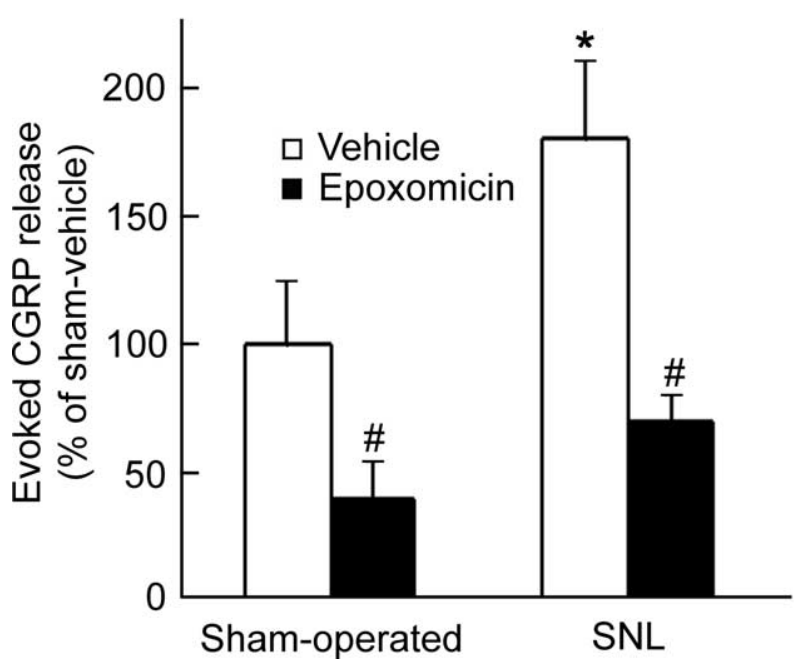

Figure 3. Epoxomicin normalizes evoked CGRP release after SNL. The dorsal quadrants ipsilateral to the side of injury in the spinal cord of rats treated for $7 \mathrm{~d}$ with vehicle or epoxomicin (twice-daily i.t. injections of $0.6 \mathrm{nmol}$ ) were taken $18 \mathrm{~h}$ after the last injection, minced, and superfused with Kreb's buffer. Epoxomicin or vehicle injections were started at the same time as the SNL or sham surgeries. $\boldsymbol{A}$, Release was induced by capsaicin ( $1 \mu \mathrm{m}$; infusion from 12 to 18 $\mathrm{min}$ ) and (GRP content was determined in 3 min superfusate fractions and presented as femtomoles of tissue per milligram fraction. A delay in the peak of CGRP release after capsaicin activation was caused by transit time in the tubing. $\boldsymbol{B}$, Epoxomicin effects on capsaicin-induced CGRP release (peptide levels above baseline) after sham operation or SNL. Capsaicin-induced release in sham-operated, vehicle-treated animals was taken as $100 \%$. Error bars indicate mean \pm SEM of the percentage of induced release obtained from sham-operated rats. ${ }^{*}, * \leq$ 0.05 , comparison between sham- and SNL-operated animals injected with vehicle $\left(^{*}\right)$ or between respective vehicle and epoxomicin groups $\left({ }^{\#}\right) ; n=7$ per group.

may be a result of degradation by extracellular peptidases. To address this possibility, we incubated the medium obtained from control cell cultures and from cells preincubated with $100 \mathrm{~nm}$ epoxomicin for $16 \mathrm{~h}$, with and without synthetic dynorphin $\mathrm{A}$ $(100 \mathrm{nM})$ for $6 \mathrm{~h}$ at $37^{\circ} \mathrm{C}$. Levels of endogenous dynorphin A and the synthetic peptide were then measured by dynorphin A RIA. No differences in the levels of endogenous or synthetic dynorphin A between samples incubated at $37^{\circ} \mathrm{C}$ or extracted before the incubation were observed. Thus, incubation of cells with ep- 


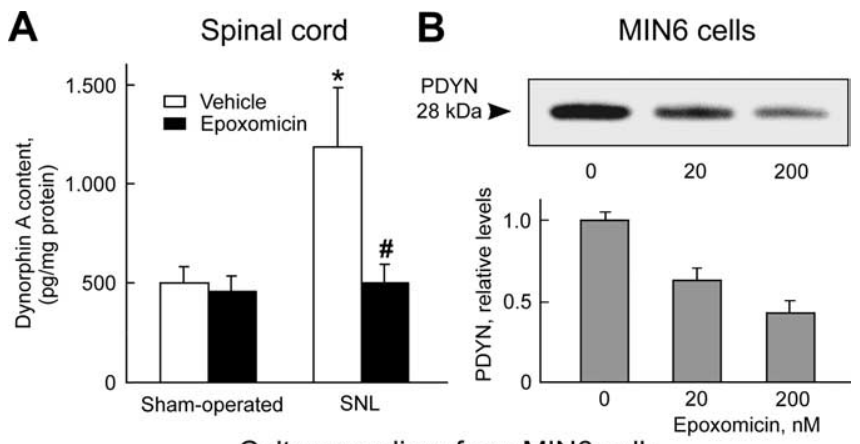

C
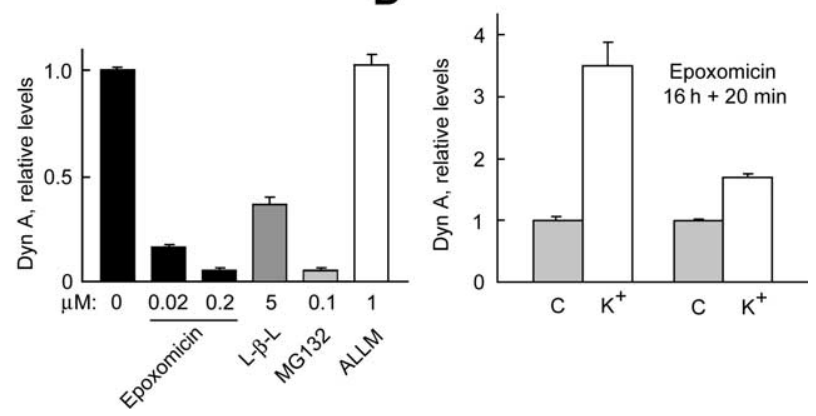

Figure 4. Effects of proteasome inhibitors on the PDYN system. $\boldsymbol{A}$, Epoxomicin blocks upregulation of dynorphin $A$ in the spinal cord of SNL rats. The dorsal quadrants ipsilateral to the side of injury in the spinal cord of rats treated for $7 \mathrm{~d}$ with epoxomicin (twice-daily i.t. injections of $0.6 \mathrm{nmol}$ ) were analyzed. $\boldsymbol{B}-\boldsymbol{D}$, Effects of epoxomicin on the PDYN levels in mouse insulinoma MIN6 cells and the dynorphin A secretion by these cells into the medium. $\boldsymbol{B}$, PDYN was analyzed in cell extracts by Western blotting. $\boldsymbol{C}, \boldsymbol{D}$, Dynorphin A levels were measured in the culture medium by RIA. $B, C$, Cells were grown for $16 \mathrm{~h}$ in the presence of 20 or $200 \mathrm{~nm}$ epoxomicin, 100 nm MG132, $5 \mu$ m clasto-lactacystine $\beta$-lactone, $1 \mu \mathrm{m} \mathrm{ALLM}$, or $0.003 \%$ DMSO used as a solvent for proteasome inhibitors. The presence of DMSO did not affect the PDYN or dynorphin A levels. Relative levels are shown as mean $\pm \mathrm{SEM} ; n=3$. D, Cells cultivated in presence of $100 \mathrm{~nm}$ epoxomicin or DMSO for $16 \mathrm{~h}$ were washed and incubated in the medium with $5.9 \mathrm{~mm}$ [control (C)] or 20 mм potassium ( $\mathrm{K}^{+}$; depolarization medium) for $20 \mathrm{~min}$. Relative levels are shown as mean $\pm \mathrm{SEM} ; n=4$. ${ }^{*}, \# \leq 0.05$, comparison between sham- and SNL-operated animals injected with vehicle $\left(^{*}\right)$ or between respective vehicle and epoxomicin groups $\left(^{\#}\right)$.

oxomicin did not change the rate of degradation of dynorphin A released from cells to the medium. A number of viable cells did not significantly differ between cultures incubated with $20 \mathrm{nM}$ epoxomicin for $18 \mathrm{~h}(82 \pm 3 \%)$ and control cultures $(100 \pm 1 \%)$, as assessed with MTT assay. No differences in all studied parameters were observed between cells cultivated in the presence and absence of vehicle $(0.003 \%$ DMSO). Together, these results demonstrate that epoxomicin strongly, and at low nanomolar concentrations, inhibits the stimulated secretion of dynorphins by PDYN-producing cells and, to a lesser extent, PDYN synthesis.

\section{Effects of epoxomicin on the UPS in SNL rats}

Antinociceptive effects of proteasome inhibitors suggest that the status of the UPS in SNL rats is important for the development and/or maintenance of neuropathic pain. To evaluate effects of SNL on the UPS we measured (1) the levels of proteins at the beginning and the end of the UPS enzymatic cascade, the ubiquitin activating enzyme E1A and the 20S proteasome, respectively, and those of free ubiquitin, ubiquitilated proteins, ubiquitin C-terminal hydrolase L1 (UCH-L1), and synaptophysin, a UPS substrate (Wheeler et al., 2002) regulating secretion of neuromediators (Fig. 5A, B,C), and (2) proteasome activity (Fig. 5E). Representative Western blot images are shown in Figure $5 A$. The levels of E1A, 20S proteasome, and free ubiquitin were decreased in SNL rats (Fig. 5B). The content of synaptophysin was increased in SNL rats (Fig. 5C), which is consistent with a previous report (Chou et al., 2002). No significant changes were observed in the levels of ubiquitilated proteins, UCH-L1, and proteasome activity in the spinal cord under the neuropathic pain condition (Fig. $5 B, E)$. Epoxomicin treatment did not reverse the SNL effects on E1A, 20S proteasome, synaptophysin, and free ubiquitin. When UPS is inhibited, free ubiquitin, which is required for regulation of several intracellular processes, may accumulate in a form of ubiquitin-protein conjugates that do not degrade (Chen et al., 2003). The observations that epoxomicin treatment did not affect the levels of free ubiquitin in sham- and SNL-operated animals suggest that the effects of this inhibitor on secretion of dynorphin A and neuropathic pain are not mediated through the depletion of a pool of free ubiquitin. This notion is supported by the in vitro observation that incubation of MIN6 cells with epoxomicin in concentrations that inhibit dynorphin secretion results in a threefold to fourfold increase in free ubiquitin levels.

We next evaluated whether epoxomicin inhibited all of the proteasome in the spinal cord (Fig. $5 E$ ). Epoxomicin covalently binds to the proteasome and irreversibly inhibits its chymotrypsin-like activity (Meng et al., 1999). Consistently, treatment of MIN6 cells with 20 nM epoxomicin for $18 \mathrm{~h}$ completely inhibited the chymotrypsin-like activity (Fig. 5D). No inhibition of the proteasome was detected in spinal cord tissue of sham- or SNL-operated animals treated with epoxomicin for $7 \mathrm{~d}$ and taken for analysis 1 or $18 \mathrm{~h}$ after the last injection (Fig. 5E). Observed chymotrypsin-like activity was associated with proteasome because it was inhibited by $25 \mu \mathrm{M}$ clastolactacystin $\beta$-lactone.

\section{Effects of epoxomicin on NF- $\kappa \mathrm{B}$ transcription factors}

Transcription factors of the nuclear factor (NF)- $\kappa \mathrm{B}$ family are apparently involved in the development of pathological pain and their inhibition may prevent this process (Laughlin et al., 2000; Tegeder et al., 2004; Ledeboer et al., 2005; Xie et al., 2006). These observations, and also the fact that activation of NF- $\kappa \mathrm{B}$ in cell cultures is blocked by proteasome inhibitors (Cusack, 2003), suggest that effects of epoxomicin and MG132 on neuropathic pain are mediated through the NF- $\kappa \mathrm{B}$ system. To test this hypothesis, we analyzed the spinal cord of sham and SNL rats for DNA binding activity of NF- $\kappa \mathrm{B}$ and p50 homodimer, identified previously by us and others in the CNS (Bakalkin et al., 1993; O'Neill and Kaltschmidt, 1997). EMSA demonstrated that the levels of NF- $\kappa \mathrm{B}$ and p50 homodimer DNA binding activity in SNL animals $(168 \pm 38 \%$ and $142 \pm 24 \%$, respectively; $n=9)$ were not significantly different from those of sham-operated rats $(100 \pm 11 \%$ and $100 \pm 9 \%$, respectively; $n=10$ ). Epoxomicin had no significant effect on DNA binding activity of these factors in SNL and sham-operated rats. Thus, administration of the proteasome inhibitor did not induce general changes in the NF- $\kappa$ B system in SNL rats.

\section{Epoxomicin-treated rats are resistant to dynorphin A-induced pain}

Dynorphin A, an endogenous opioid peptide produces a longlasting allodynia and hyperalgesia in rodents, behavioral states consistent with signs of clinically observed neuropathic pain. This dynorphin-induced allodynia was used as a pharmacological model of enhanced abnormal pain (Laughlin et al., 1997; Vanderah et al., 2000). In addition to inhibition of upregulation and secretion of spinal dynorphin A, proteasome inhibitors may interfere with actions of dynorphin A at the "postsynaptic" levels, resulting in allodynia and hyperalgesia. To test this hypothesis, 
dynorphin A (15 nmol) or saline was injected intrathecally into animals that also received either epoxomicin $(0.6 \mathrm{nmol} /$ dose, twice daily; peptide was injected on the first day of treatment with proteasome inhibitor) or vehicle (5\% DMSO in 95\% saline) for $5 \mathrm{~d}$, and responses to light tactile stimuli and hot-plate latencies were evaluated daily over a period of $9 \mathrm{~d}$ (Fig. 6). Whereas dynorphin A alone induced enhanced behavioral signs of pathological pain, behavioral signs of tactile allodynia (Fig. 6A) and thermal hyperalgesia (Fig. $6 B$ ) were mostly abolished by epoxomicin treatment. The paw withdrawal thresholds were significantly reduced $\left(F_{(9,50)}=13.66\right.$; $\left.p=9.8 \times 10^{-11}\right) 2 \mathrm{~d}$ after dynorphin $\mathrm{A}$ administration compared with the predynorphin A baseline values. Paw withdrawal thresholds of the epoxomicintreated animals given dynorphin A were greater than those of the vehicle-treated animals that received dynorphin A over 4-6 d of epoxomicin treatment period $\left(F_{(9,50)}=4.93 ; p=9.57 \times 10^{-5}\right)$, but were still reduced compared with predynorphin levels. The hot-plate latencies were significantly reduced $\left(F_{(9,50)}=5.038 ; p=7.7 \times\right.$ $10^{-5}$ ) relative to the predynorphin baseline values. Termination of epoxomicin injections on the day 5 of treatment led to a progressive appearance of enhanced responses to tactile and thermal stimuli. Repeated injections of epoxomicin did not produce significant elevations in hot-plate latencies of the vehicle-treated $\left(F_{(9,40)}=\right.$ $1.363 ; p=0.2369)$ or dynorphin-treated $\left(F_{(9,50)}=1.556 ; p=0.1547\right)$ groups. These observations argue against any significant sensory deficit induced by exposure to epoxomicin over the dose-range and timeframe used. Thus, epoxomicin produces multiple effects; in addition to the inhibition of dynorphin A upregulation, this compound also blocks nociceptive behavior elicited by dynorphin A.

\section{Epoxomicin prevents pathological pain induced by sustained morphine administration}

Persistent exposure to morphine produces tactile allodynia and thermal hyperalgesia within $3 \mathrm{~d}$. Male Sprague Dawley rats were prepared with a subcutaneous implantation of a pair of placebo pellets or pellets each containing $75 \mathrm{mg}$ of morphine free base. The rats also received twice-daily spinal injections of either epoxomicin (0.6 $\mathrm{nmol}$ ) or vehicle, beginning on the day of implantation. Paw withdrawal thresholds and hot-plate latencies were monitored daily before the first injection of the day. Rats receiving opioid and vehicle injec-
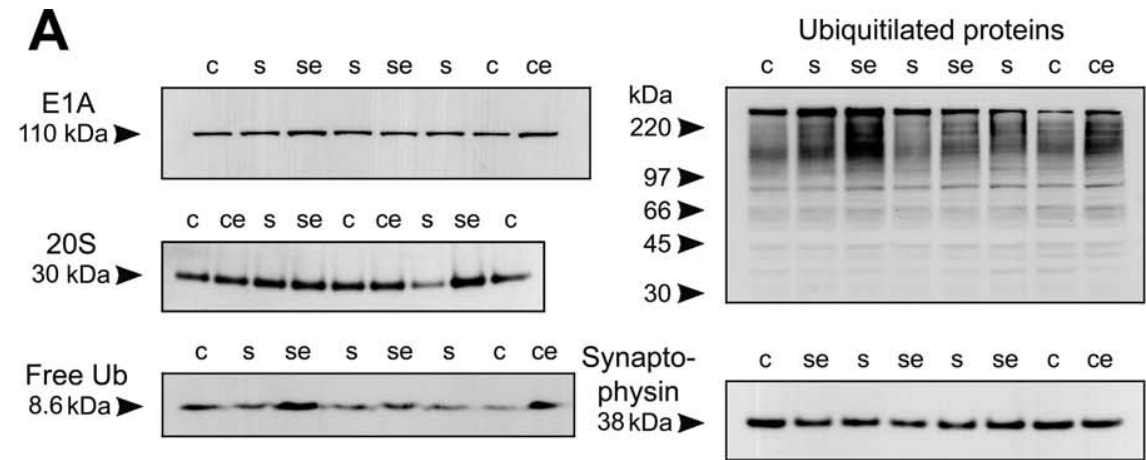

c ce $\mathrm{s}$ se $\mathrm{c}$ c ce $\mathrm{s}$ se $\mathrm{c}$
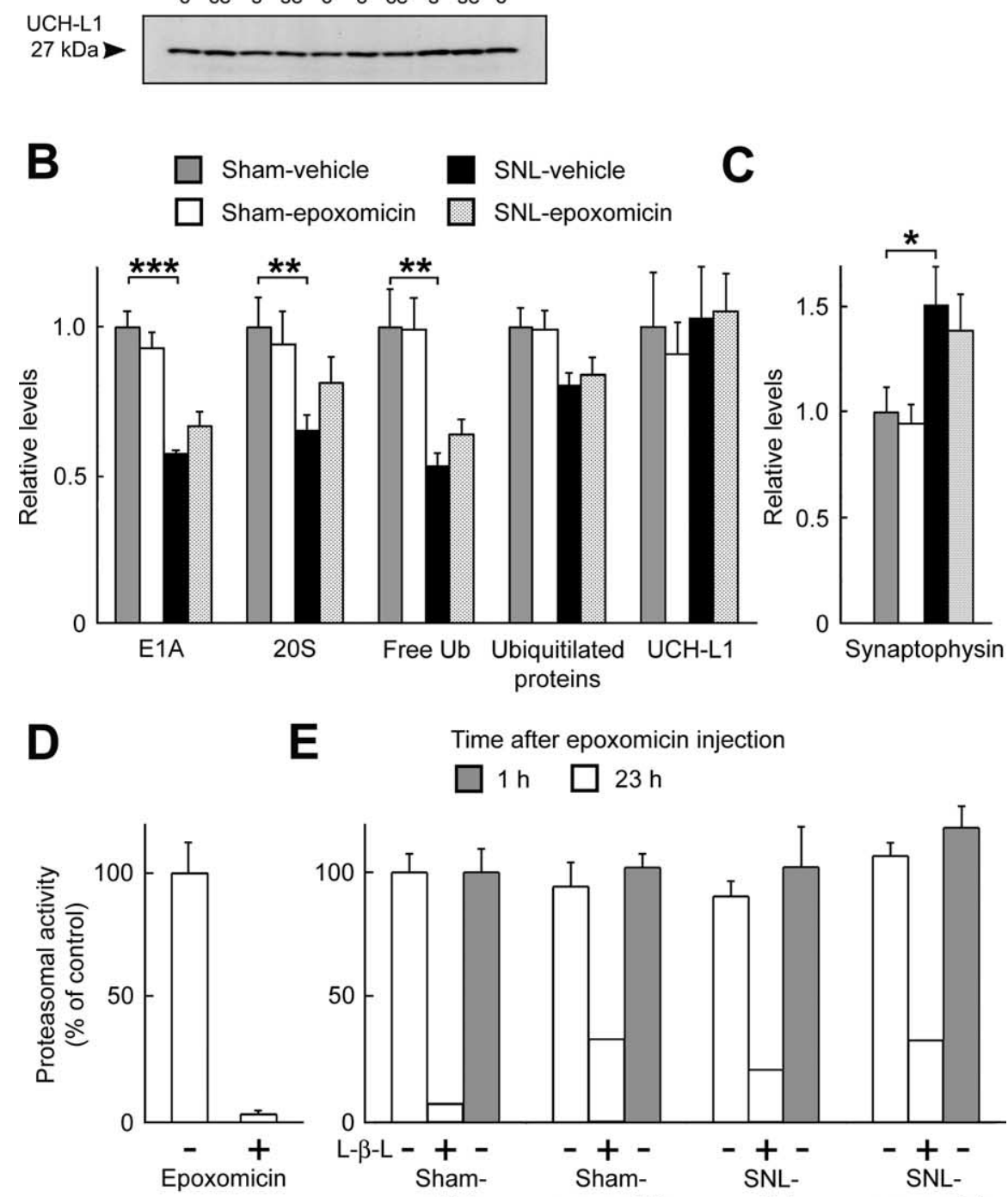

E Time after epoxomicin injection

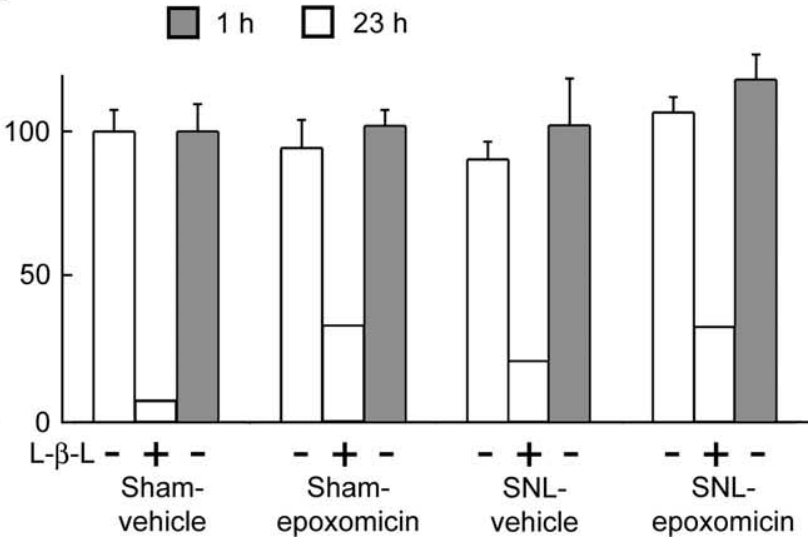

Figure 5. Effects of epoxomicin on the UPS proteins and synaptophysin in spinal cord tissues from sham-operated and SNL animals. $\boldsymbol{A}-\boldsymbol{C}, \boldsymbol{E}$, Rats with SNL or sham surgery received vehicle or epoxomicin $(0.6 \mathrm{nmol} /$ dose $)$ twice daily for $7 \mathrm{~d}$ and ipsilateral quadrants of the spinal cord relative to the injury side were taken for analysis $18 \mathrm{~h}(\boldsymbol{A}, \boldsymbol{B}, \boldsymbol{C})$ or $23 \mathrm{~h}(\boldsymbol{E})$ after the last injection, or $1 \mathrm{~h}$ after the first daily injection $(\boldsymbol{E})$. $\boldsymbol{A}$, Representative Western blot images. c, Sham-vehicle; ce, sham-epoxomicin; $\mathbf{S}$, SNL-vehicle; se, SNL-epoxomicin. $\boldsymbol{B}$, Levels of E1A ubiquitin-activating enzyme, $20 \mathrm{~S}$ proteasome subunit, free ubiquitin, ubiquitilated proteins, and ubiquitin C-terminal hydrolase L1. Error bars indicate mean \pm SEM; the levels in sham-operated animals are taken as a unit. ${ }^{*} p \leq 0.05 ;{ }^{* *} p \leq 0.01 ;{ }^{* * *} p \leq 0.001 ; n=4-10$. The key in $\boldsymbol{B}$ also applies to $\boldsymbol{C}$. $\boldsymbol{C}$, Levels of synaptophysin. $\boldsymbol{D}$, Inhibition of chymotrypsin-like proteasome activity in MIN6 cells incubated with $20 \mathrm{~nm}$ epoxomicin for $18 \mathrm{~h}$. Data are presented as mean $\pm \mathrm{SEM} ; n=2$ for the control group, $n=3$ for the epoxomicin-treated group. $\boldsymbol{E}$, Chymotrypsin-like activity in spinal cord tissues from control and SNL animals. Animals were killed before the first daily injection (open bars; $n=4-6$ ) or $1 \mathrm{~h}$ after the first daily injection (gray bars; $n=8-10)$. Clasto-lactacystin- $\beta$-lactone (L- $\beta$-L) was added to the pooled samples from first experiment to test whether hydrolysis of fluorogenic substrate Suc-LLVY-AMC was catalyzed by the proteasome. Data are shown as mean \pm SEM. 
A Tactile hyperesthesia

$\circ$ Vehicle-vehicle Dynorphin A-vehicle
$\square$ Vehicle-epoxomicin @ Dynorphin A-epoxomicin

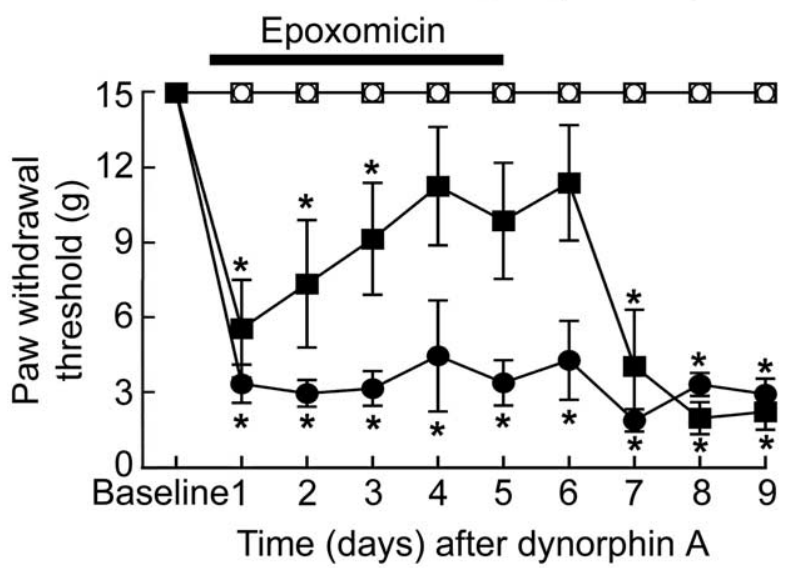

B

Thermal hyperalgesia

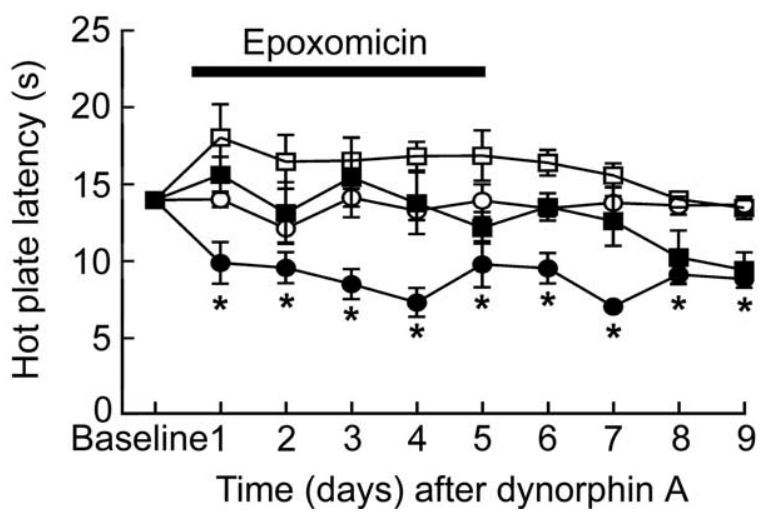

Figure 6. Epoxomicin abolished dynorphin-induced tactile allodynia and thermal hyperalgesia. $\boldsymbol{A}, \boldsymbol{B}$, Responsive thresholds to innocuous mechanical (von Frey filaments; $\boldsymbol{A}$ ) and thermal $\left(52^{\circ} \mathrm{C}\right.$ hot-plate; $\left.\boldsymbol{B}\right)$ stimuli. Dynorphin $\mathrm{A}(15 \mathrm{nmol})$ was injected intrathecally and twice-daily injections of epoxomicin or vehicle were initiated at the same time. Rats that received dynorphin and vehicle developed enhanced responses to tactile and thermal stimuli, whereas those treated with epoxomicin did not. Termination of epoxomicin resulted in a decreased response thresholds to tactile and thermal stimuli. ${ }^{*} p \leq 0.05$, compared to the predynorphin or vehicle baseline values within each treatment group. Data are shown as mean \pm SEM; $n=4-6$ per group.

tions developed tactile allodynia and thermal hyperalgesia, as indicated by significant reductions in response endpoints (Fig. 7). Paw withdrawal thresholds of morphine-treated rats receiving vehicle injections were significantly $\left(F_{(7,24)}=18.01 ; p=3.93 \times\right.$ $10^{-8}$ ) reduced from a pooled baseline value of $15 \pm 0$ to $3.32 \pm$ $0.57 \mathrm{~g}$ and hot-plate latencies were significantly $\left(F_{(7,40)}=18.7\right.$; $p=8.74 \times 10^{-11}$ ) reduced from a pooled baseline value of $23.89 \pm 1.20$ to $15.2 \pm 1.20 \mathrm{~s}$. Treatment with epoxomicin prevented the development of both tactile allodynia (Fig. 7A) and thermal hyperalgesia (Fig. $7 B$ ). The paw withdrawal thresholds of the epoxomicin-treated rats with morphine pellets were not reduced over the $7 \mathrm{~d}$ observation period, and the withdrawal thresholds were significantly $\left(F_{(1,72)}=227 ; p=5.90 \times 10^{-24}\right)$ greater than those of the vehicle-treated group given morphine pellets. Likewise, the hot-plate latencies of the morphine-treated rats receiving epoxomicin were not significantly reduced over the $7 \mathrm{~d}$ observation period, and were significantly $\left(F_{(1,80)}=81.1 ; p=\right.$

\section{Tactile hyperesthesia}

\section{o Placebo-vehicle • Morphine-vehicle $\checkmark$ Placebo-epoxomicin a Morphine-epoxomicin}

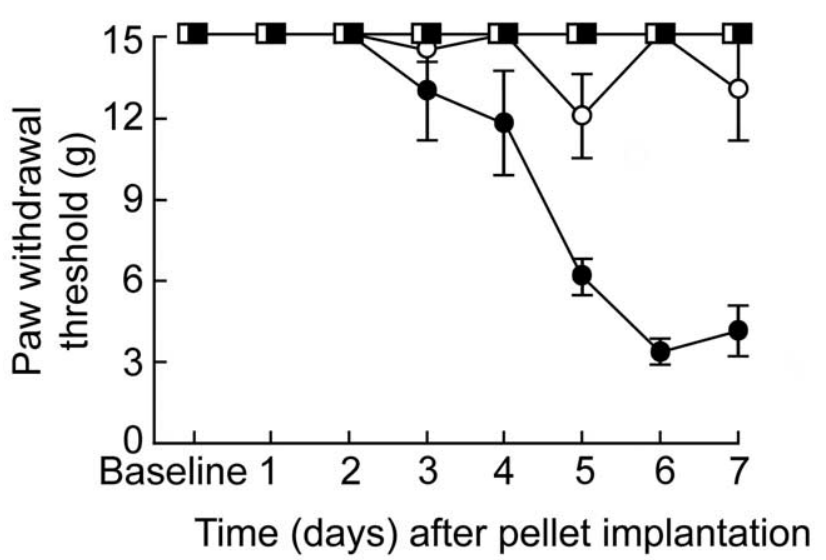

B Thermal hyperalgesia

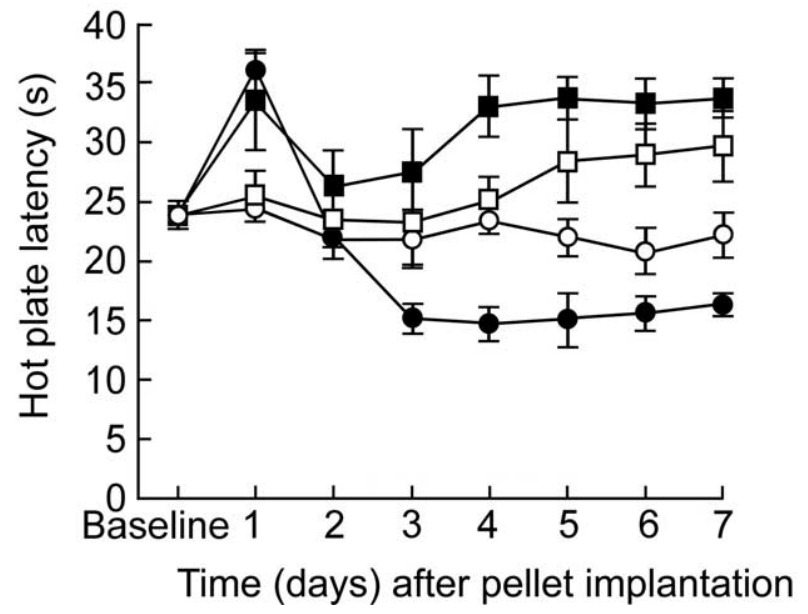

Figure 7. The proteasome inhibitor epoxomicin prevents morphine-induced tactile allodynia and thermal hyperalgesia. Rats were prepared with either placebo or morphine $(2 \times 75$ $\mathrm{mg})$ pellets implanted subcutaneously. The rats also received vehicle or epoxomicin $(0.6 \mathrm{nmol}$, i.t.) twice daily. $\boldsymbol{A}, \boldsymbol{B}$, Morphine-treated rats receiving vehicle intrathecally developed tactile allodynia $(\boldsymbol{A})$ and thermal hyperalgesia $(\boldsymbol{B})$, as indicated by the reductions in paw withdrawal thresholds and hot-plate latencies. In contrast, morphine-treated rats receiving epoxomicin did not develop these reductions in behavioral endpoints. Data are shown as mean \pm SEM. $n=$ 4-7 per group.

$8.0 \times 10^{-14}$ ) greater than those of the morphine-treated group receiving vehicle injections, suggesting an unmasking of the antinociceptive effects of morphine (Fig. $7 B$ ). Vehicle-treated rats that also received epoxomicin developed moderate increases in hot-plate latencies that were not statistically significant $\left(F_{(7,40)}\right.$ $=0.8033 ; p=0.5895)$. Thus, in control groups of animals (Figs. $1 B, D, F, 6 B, 7 B$ ), the increases in hot-plate latencies induced by the 5-7 d of continuous treatment with epoxomicin or MG132 were (1) lower in amplitude compared with those in rats with chronic pain and were (2) statistically significant in one of five experiments, suggesting that this is not a consistent phenomenon. 
Evaluation of potential neurotoxicity or behavioral toxicity Rats that received twice-daily injections of MG132 $(5 \mathrm{mg} / \mathrm{kg}$ per day, s.c.) or of spinal epoxomicin ( $0.6 \mathrm{nmol}$ per injection) for $7 \mathrm{~d}$ were examined for overt behavioral signs of motor dysfunction on the rotarod, according to a behavioral protocol we have described previously (Gardell et al., 2003b). The cutoff latency for that test was $120 \mathrm{~s}$. Treatment with MG132 did not produce any signs of overt motor dysfunction and did not reduce the ability of the rat to maintain balance on the rotarod ( $n=6 /$ group). All rats that received MG132 remained on the rotarod for $120 \mathrm{~s}$ or longer on each of the days tested. The rats treated with epoxomicin demonstrated a moderate, but not statistically significant $\left(F_{(6,35)}=1.943 ; p=0.101 ; n=6 /\right.$ group $)$ reduction in time spent on the rotarod, declining from $120 \mathrm{~s}$ on day 1 to $77 \pm 39 \mathrm{~s}$ on day 7. This change might be attributable to sedative effects, although the possibility of behavioral toxicity caused by cumulative effects of the epoxomicin infusions cannot be ruled out. However, no signs of dead or dying cells were identified with Fluoro-Jade B staining in spinal cord sections of sham- and SNL rats treated with either epoxomicin or MG132 and examined after termination of the rotarod experiments. In addition, the rats were observed for signs of adverse primary overt behaviors. None of the rats examined demonstrated any obvious adverse changes in posture, gait, or exploratory locomotor activity.

\section{Discussion}

A previous study with single spinal injections of proteasome inhibitors in rats with CCI indicated that the UPS may contribute to mechanisms supporting neuropathic pain (Moss et al., 2002). We confirm and extend these observations, and provide here compelling evidence demonstrating that the UPS is a critical component for the manifestation of behavioral signs of chronic pain. Our principal findings argue that (1) inhibition of UPS activity abolishes the initiation and maintenance of neuropathic pain, (2) proteasome inhibitors given spinally or systemically abolish signs of pathological pain, and (3) proteasome inhibition also blocks pathological pain induced by sustained morphine or dynorphin A, a mediator of central sensitization.

We have repeatedly shown that behavioral signs of neuropathic pain correlate with the upregulation of spinal dynorphin $\mathrm{A}$ and enhancement of capsaicin-evoked release of CGRP from primary afferent terminals (Malan et al., 2000; Wang et al., 2001; Burgess et al., 2002; Gardell et al., 2003a, 2004; Xu et al., 2004). These behavioral and biochemical consequences of nerve injury are abolished by disrupting descending facilitation from medullary sites. Similar results were made after persistent exposure to opioids (for review, see Ossipov et al., 2001, 2005; Ossipov and Porreca, 2005, 2006). In the present study, epoxomicin abolished the upregulation of spinal dynorphin A and enhanced capsaicinevoked release of CGRP elicited by SNL. Normalization of both evoked CGRP release and dynorphin A upregulation may be a consequence of the inhibition of the development and maintenance of neuropathic pain by epoxomicin. However, experiments with a model cell line demonstrated that the dynorphin system may be directly targeted by proteasome inhibitors; our preliminary data suggest that these effects are mediated via inhibition of PDYN trafficking in the regulated secretory pathway and depletion of processing convertase PC2 essential for the processing. We and others demonstrated that dynorphin A promotes pain acting through activation of the glutamate and/or bradykinin receptors (Lai et al., 2006) that both are under the control of the UPS (Patrick et al., 2003; Bachar et al., 2004; Moriyoshi et al., 2004). Collectively, these findings suggest that effects of protea- some inhibitors on chronic pain are mediated through several protein systems, including those controlling dynorphin A and CGRP release and postsynaptic actions of dynorphin A.

Other mechanisms may involve the UPS-regulated protein kinase $\mathrm{A}$, which contributes to central sensitization and abnormal pain (Moss et al., 2002), and voltage-dependent calcium channels (VDCCs). Inhibition of the UPS markedly reduced the activity of VDCCs in endocrine and neuronal cells (Ehlers, 2003; Kawaguchi et al., 2006), and blockade of these channels abolishes central sensitization and enhanced abnormal pain after nerve injury or opioid exposure (Dogrul et al., 2005; Hildebrand and Snutch, 2006). Effects of proteasome inhibitors on CGRP and dynorphin may result from inhibition of VDCC activity. Actions of proteasome inhibitors mediated through inhibition of NF- $\kappa$ B activation in the spinal cord may probably be ruled out; our EMSA data does not support this hypothesis.

Consistent with previous studies, we did not observe a significant inhibition of proteasome activity in animals treated with the irreversible inhibitor epoxomicin at the dose that prevented the development of chronic pain. Epoxomicin acts on cultured neurons at concentrations of 1-10 $\mu \mathrm{M}$ (Fornai et al., 2003; Willeumier et al., 2006). Estimating spinal CSF volume as $200 \mu \mathrm{l}$ (Bass and Lundberg, 1973; De La Riva and Yeo, 1985), a spinal injection of epoxomicin $(0.6 \mathrm{nmol})$ results in a CSF concentration of $3 \mu \mathrm{M}$ in the fluid, which could be sufficient to inhibit proteasome in the superficial cell layers. However, assuming uniform distribution, epoxomicin concentration would be $<0.3 \mu \mathrm{M}$ and, thus, too low to inhibit the proteasome in the majority of cells. Consistently, a 50\% inhibition of proteasome activity occurred after infusion of $10 \mu \mathrm{mol}$ epoxomicin into the rat striatum (Fornai et al., 2003), representing a 20,000-fold higher concentration than that used in the present study. Neurons in the superficial layers of the spinal cord and in the dorsal root ganglion, or primary afferent fibers projecting into the dorsal horns may be more accessible to this compound. Furthermore, proteasome inhibitors may target selective neuronal subpopulations with a higher rate of the UPS-mediated protein degradation, such as injured neurons. This notion is supported by the observations that intracellular calcium levels are increased after nerve injury, resulting in activation of the UPS (Ehlers, 2004). Another possibility is that intracellular concentration of inhibitors may reach the levels sufficient for proteasome inhibition in selective neuronal compartments such as synapses, for example, because of activation of retrieval endocytosis in firing neurons in pain transmission pathways.

Analysis of the status of the UPS under the condition of chronic pain demonstrated that the levels of E1A and 20S proteasome, proteins of the beginning and the end of the UPS enzymatic cascade, and those of free ubiquitin are reduced in the spinal cord of SNL animals. The UPS-mediated protein degradation may be downregulated in these rats and this, by analogy with effects of proteasome inhibitors, may counteract to the development and/or maintenance of neuropathic pain.

Effects of epoxomicin are regarded as induced through inhibition of the proteasome (Meng et al., 1999; Delcros et al., 2003; Kawaguchi et al., 2006). This statement is based on (1) the facts that this compound along with clasto-lactacystine $\beta$-lactone is probably the most selective proteasome inhibitor (Tsubuki et al., 1996, Delcros et al., 2003), (2) the absence of data on side-effects, despite of extensive studies of this inhibitor, (3) a similarity in effects of proteasome inhibitors of different chemical structures, and (4) a similarity in effects of these inhibitors and UPS genetic modifications (An et al., 2006; Ding et al., 2006). However, direct 
evidence for this statement is lacking and this is the limitation of our and other in vivo studies. We limit our approach to analysis of actions of proteasome inhibitors on chronic pain assuming, similarly to other studies (Meng et al., 1999; Moss et al., 2002; Delcros et al., 2003; Kawaguchi et al., 2006), that these compounds interfere with UPS functions.

In rats, the proteasome inhibitor bortezomib induced mildto-moderate neurotoxic effects when given intravenously on a schedule of two or three injections per week (Cavaletti et al., 2007) and, in cancer patients, neuropathic pain is emerging as a major complication of treatment with this inhibitor (Cata et al., 2006). Thus, effects of proteasome inhibitors on pathological pain observed in the present study may be a consequence of neurotoxicity or interference with normal neurotransmission. Several observations argue against this interpretation. First, neurotoxic effects in rats were observed with multiple intravenous administrations of the maximum tolerated sublethal dose of bortezomib. Because bortezomib is 100- to 1000 -fold more potent then MG132 (Berkers et al., 2005; Saulle et al., 2007), the MG132 dose administered subcutaneously in our experiments $(10 \mathrm{mg} / \mathrm{kg} / \mathrm{d}$ of treatment) that produced antinociceptive effects may be regarded as similar or much lower then a single dose or cumulative doses of intravenous bortezomib (0.08 and $0.15 \mathrm{mg} /$ $\mathrm{kg} / \mathrm{d}$ of treatment, twice weekly for 4 weeks), which did not produce any pathological changes (Cavaletti et al., 2007). Second, effects of bortezomib on nerve conduction velocity were registered on the 14th day after the initiation of injections, whereas MG132 and epoxomicin inhibited neuropathic pain already on the first or second day of treatment. Third, bortezomib may induce neurotoxic effects through a component in its activity that is blocked by the polyhydroxyl compound Tiron, a radical spin trap; this component lacks in actions of MG132 (Fernandez et al., 2006). Further arguing against the possibility that reversal of tactile allodynia or thermal hyperalgesia are secondary to neurotoxic effects of the proteasome inhibitors are the observations that, during 5-7 d of continuous treatment with MG132 or epoxomicin, antinociceptive effects were evident whereas (1) there were no changes in sensory responses to mechanical or, with the exception of one of five experiments, thermal stimuli in sham operated animals, (2) no (MG132) or statistically insignificant (epoxomicin) effects on motor performance on the rotarod, (3) no adverse changes in posture, gait, or exploratory locomotor activity, and (4) no cell death in the spinal cord. Moreover, termination of the injections of the reversible inhibitor MG132 and of the irreversible inhibitor epoxomicin was rapidly followed by restoration of both tactile allodynia and thermal hyperalgesia in rats with SNL, arguing against the induction of irreversible deficits by both inhibitors. Thus, the window between antinociceptive and cytotoxic effects is large for both systemic MG132 and spinal epoxomicin. Nonetheless, the utility of proteasome inhibitors for treatment of clinical pain might be compromised by the potential for neurotoxicity of the currently available compounds after chronic administration. Focus on E3 ubiquitin ligases as specific drug targets might be a more promising approach.

In conclusion, our data that proteasome inhibitors block tactile allodynia and thermal hyperalgesia as well as that of enhanced capsaicin-evoked release of CGRP and upregulation of spinal dynorphin suggest that the UPS is a critical intracellular regulator of chronic pathological pain. Additional mechanistic investigation of the effects of proteasome inhibition on neurotransmitter release, VDCC regulation, and glutamatergic signaling is required for understanding of central sensitization.

\section{References}

Adams J, Behnke M, Chen S, Cruickshank AA, Dick LR, Grenier L, Klunder JM, Ma YT, Plamondon L, Stein RL (1998) Potent and selective inhibitors of the proteasome: dipeptidyl boronic acids. Bioorg Med Chem Lett 8:333-338.

An JY, Seo JW, Tasaki T, Lee MJ, Varshavsky A, Kwon YT (2006) Impaired neurogenesis and cardiovascular development in mice lacking the E3 ubiquitin ligases UBR1 and UBR2 of the N-end rule pathway. Proc Natl Acad Sci USA 103:6212-6217.

Angst MS, Clark JD (2006) Opioid-induced hyperalgesia: a qualitative systematic review. Anesthesiology 104:570-587.

Bachar O, Adner M, Uddman R, Cardell LO (2004) Toll-like receptor stimulation induces airway hyper-responsiveness to bradykinin, an effect mediated by JNK and NF-kappa B signaling pathways. Eur J Immunol 34:1196-1207.

Bakalkin G, Yakovleva T, Terenius L (1993) NF-kappa B-like factors in the murine brain. Developmentally regulated and tissue-specific expression. Brain Res Mol Brain Res 20:137-146.

Bass NH, Lundberg P (1973) Postnatal development of bulk flow in the cerebrospinal fluid system of the albino rat: clearance of [carboxyl14C] inulin following intrathecal infusion. Brain Res 52:323-332.

Berkers CR, Verdoes M, Lichtman E, Fiebiger E, Kessler BM, Anderson KC, Ploegh HL, Ovaa H, Galardy PJ (2005) Activity probe for in vivo profiling of the specificity of proteasome inhibitor bortezomib. Nat Methods 2:357-362.

Burgess SE, Gardell LR, Ossipov MH, Malan Jr TP, Vanderah TW, Lai J, Porreca F (2002) Time-dependent descending facilitation from the rostral ventromedial medulla maintains, but does not initiate, neuropathic pain. J Neurosci 22:5129-5136.

Cata JP, Weng HR, Burton AW, Villareal H, Giralt S, Dougherty PM (2006) Quantitative sensory findings in patients with bortezomib-induced pain. J Pain 8:296-306.

Cavaletti G, Gilardini A, Canta A, Rigamonti L, Rodriguez-Menendez V, Ceresa C, Marmiroli P, Bossi M, Oggioni N, D’Incalci M, De Coster R (2007) Bortezomib-induced peripheral neurotoxicity: A neurophysiological and pathological study in the rat. Exp Neurol 204:317-325.

Chaplan SR, Bach FW, Pogrel JW, Chung JM, Yaksh TL (1994) Quantitative assessment of tactile allodynia in the rat paw. J Neurosci Methods 53:55-63.

Chen H, Polo S, Di Fiore PP, De Camilli PV (2003) Rapid Ca ${ }^{2+}$-dependent decrease of protein ubiquitination at synapses. Proc Natl Acad Sci USA 100:14908-14913.

Chen JJ, Barber LA, Dymshitz J, Vasko MR (1996) Peptidase inhibitors improve recovery of substance $P$ and calcitonin gene-related peptide release from rat spinal cord slices. Peptides 17:31-37.

Chou AK, Muhammad R, Huang SM, Chen JT, Wu CL, Lin CR, Lee TH, Lin SH, Lu CY, Yang LC (2002) Altered synaptophysin expression in the rat spinal cord after chronic constriction injury of sciatic nerve. Neurosci Lett 333:155-158.

Christensson-Nylander I, Terenius L (1985) Dynorphin peptides in human substantia nigra. Neuropeptides 6:391-396.

Colledge M, Snyder EM, Crozier RA, Soderling JA, Jin Y, Langeberg L, Lu H, Bear M, Scott J (2003) Ubiquitination regulates PSD-95 degradation and AMPA receptor surface expression. Neuron 40:595-607.

Cusack JC (2003) Rationale for the treatment of solid tumors with the proteasome inhibitor bortezomib. Cancer Treat Rev 29 [Suppl]21-31.

De La Riva CF, Yeo JA (1985) Repeated determination of cerebrospinal fluid amine metabolites by automated direct sampling from an implanted cannula in freely moving rats. J Neurosci Methods 14:233-240.

Delcros JG, Floc'h MB, Prigent C, Arlot-Bonnemains Y (2003) Proteasome inhibitors as therapeutic agents: current and future strategies. Curr Med Chem 10:479-503.

Ding J, Allen E, Wang W, Valle A, Wu C, Nardine T, Cui B, Yi J, Taylor A, Jeon NL, Chu S, So Y, Vogel H, Tolwani R, Mobley W, Yang Y (2006) Gene targeting of GAN in mouse causes a toxic accumulation of microtubuleassociated protein 8 and impaired retrograde axonal transport. Hum Mol Genet 15:1451-1463.

Dogrul A, Bilsky EJ, Ossipov MH, Lai J, Porreca F (2005) Spinal L-type calcium channel blockade abolishes opioid-induced sensory hypersensitivity and antinociceptive tolerance. Anesth Analg 101:1730-1735.

Ehlers MD (2003) Activity level controls postsynaptic composition and signaling via the ubiquitin-proteasome system. Nat Neurosci 6:231-242. 
Ehlers MD (2004) Deconstructing the axon: Wallerian degeneration and the ubiquitin-proteasome system. Trends Neurosci 27:3-6.

Fenteany G, Standaert RF, Reichard GA, Corey EJ, Schreiber SL (1994) A beta-lactone related to lactacystin induces neurite outgrowth in a neuroblastoma cell line and inhibits cell cycle progression in an osteosarcoma cell line. Proc Natl Acad Sci USA 91:3358-3362.

Fernandez Y, Miller TP, Denoyelle C, Esteban JA, Tang WH, Bengston AL, Soengas MS (2006) Chemical blockage of the proteasome inhibitory function of bortezomib: impact on tumor cell death. J Biol Chem 281:1107-1118.

Fornai F, Lenzi P, Gesi M, Ferrucci M, Lazzeri G, Busceti CL, Ruffoli R, Soldani P, Ruggieri S, Alessandrì MG, Paparelli A (2003) Fine structure and biochemical mechanisms underlying nigrostriatal inclusions and cell death after proteasome inhibition. J Neurosci 23:8955-8966.

Gardell LR, Wang R, Burgess SE, Ossipov MH, Vanderah TW, Malan Jr TP, Lai J, Porreca F (2002) Sustained morphine exposure induces a spinal dynorphin-dependent enhancement of excitatory transmitter release from primary afferent fibers. J Neurosci 22:6747-6755.

Gardell LR, Vanderah TW, Gardell SE, Wang R, Ossipov MH, Lai J, Porreca F (2003a) Increased evoked excitatory transmitter release in experimental neuropathy requires descending facilitation. J Neurosci 23:8370-8379.

Gardell LR, Wang R, Ehrenfels C, Ossipov MH, Rossomando AJ, Miller S, Buckley C, Cai AK, Tse A, Foley SF, Gong BJ, Walus L, Carmillo P, Worley D, Huang C, Engber T, Pepinsky B, Cate RL, Vanderah TW, Lai J, et al. (2003b) Multiple actions of systemic artemin in experimental neuropathy. Nat Med 9:1383-1389.

Gardell LR, Ibrahim M, Wang R, Wang Z, Ossipov MH, Malan TP, Porreca F, Lai J (2004) Mouse strains that lack spinal dynorphin upregulation after peripheral nerve injury do not develop neuropathic pain. Neuroscience 123:43-52.

Groll M, Huber R (2004) Inhibitors of the eukaryotic 20S proteasome core particle: a structural approach. Biochim Biophys Acta 1695:33-44.

Guignard B, Bossard AE, Coste C, Sessler DI, Lebrault C, Alfonsi P, Fletcher D, Chauvin M (2000) Acute opioid tolerance: intraoperative remifentanil increases postoperative pain and morphine requirement. Anesthesiology 93:409-417.

Gureje O, Von Korff M, Simon GE, Gater R (1998) Persistent pain and well-being: a World Health Organization study in primary care. JAMA 280:147-151.

Hansson P, Lacerenza M, Marchettini P (2001) Aspects of clinical and experimental neuropathic pain: the clinical perspective. In: Neuropathic pain: pathophysiology and treatment (Hansson P, Fields H, Hill RG, Marchettini P, eds), pp 1-18. Seattle: IASP.

Hildebrand ME, Snutch TP (2006) Contributions of T-type calcium channels to the pathophysiology of pain signaling. Drug Discov Today: Disease Mechanism 3:335-341.

Joly V, Richebe P, Guignard B, Fletcher D, Maurette P, Sessler DI, Chauvin M (2005) Remifentanil-induced postoperative hyperalgesia and its prevention with small-dose ketamine. Anesthesiology 103:147-155.

Josefsen K, Buschard K, Sorensen LR, Wollike M, Ekman R, Birkenbach M (1998) Glucose stimulation of pancreatic beta-cell lines induces expression and secretion of dynorphin. Endocrinology 139:4329-4336.

Kawaguchi M, Minami K, Nagashima K, Seino S (2006) Essential role of ubiquitin-proteasome system in normal regulation of insulin secretion. J Biol Chem 281:13015-13020.

Kim SH, Chung JM (1992) An experimental model for peripheral neuropathy produced by segmental spinal nerve ligation in the rat. Pain 50:355-363.

Kisselev AF, Goldberg AL (2001) Proteasome inhibitors: from research tools to drug candidates. Chem Biol 8:739-758.

Lai J, Luo MC, Chen Q, Ma S, Gardell LR, Ossipov MH, Porreca F (2006) Dynorphin A activates bradykinin receptors to maintain neuropathic pain. Nat Neurosci 9:1534-1540.

Laughlin TM, Vanderah TW, Lashbrook J, Nichols ML, Ossipov M, Porreca F, Wilcox GL (1997) Spinally administered dynorphin A produces longlasting allodynia: involvement of NMDA but not opioid receptors. Pain 72:253-260.

Laughlin TM, Bethea JR, Yezierski RP, Wilcox GL (2000) Cytokine involvement in dynorphin-induced allodynia. Pain 84:159-167.

Ledeboer A, Gamanos M, Lai W, Martin D, Maier SF, Watkins LR, Quan N
(2005) Involvement of spinal cord nuclear factor kappaB activation in rat models of proinflammatory cytokine-mediated pain facilitation. Eur J Neurosci 22:1977-1986.

Malan TP, Ossipov MH, Gardell LR, Ibrahim M, Bian D, Lai J, Porreca F (2000) Extraterritorial neuropathic pain correlates with multisegmental elevation of spinal dynorphin in nerve-injured rats. Pain 86:185-194.

Meng L, Mohan R, Kwok BH, Elofsson M, Sin N, Crews CM (1999) Epoxomicin, a potent and selective proteasome inhibitor, exhibits in vivo antiinflammatory activity. Proc Natl Acad Sci USA 96:10403-10408.

Miyazaki J, Araki K, Yamato E, Ikegami H, Asano T, Shibasaki Y, Oka Y, Yamamura K (1990) Establishment of a pancreatic beta cell line that retains glucose-inducible insulin secretion: special reference to expression of glucose transporter isoforms. Endocrinology 127:126-132.

Moriyoshi K, Iijima K, Fujii H, Ito H, Cho Y, Nakanishi S (2004) Seven in absentia homolog 1 A mediates ubiquitination and degradation of group 1 metabotropic glutamate receptors. Proc Natl Acad Sci USA 101:8614-8619.

Mosmann T (1983) Rapid colorimetric assay for cellular growth and survival: application to proliferation and cytotoxicity assays. J Immunol Methods 65:55-63.

Moss A, Blackburn-Munro G, Garry EM, Blakemore JA, Dickinson T, Rosie R, Mitchell R, Fleetwood-Walker SM (2002) A role of the ubiquitinproteasome system in neuropathic pain. J Neurosci 22:1363-1372.

Nicholson BD (2003) Diagnosis and management of neuropathic pain: a balanced approach to treatment. J Am Acad Nurse Pract 15:3-9.

Ohayon MM, Schatzberg AF (2003) Using chronic pain to predict depressive morbidity in the general population. Arch Gen Psychiatry 60:39-47.

O’Neill LA, Kaltschmidt C (1997) NF-kappa B: a crucial transcription factor for glial and neuronal cell function. Trends Neurosci 20:252-258.

Ossipov MH, Porreca F (2005) Descending modulation of pain. In: The paths of pain (Merskey H, Loeser JD, Dubner R, eds). Seattle: IASP.

Ossipov MH, Porreca F (2006) Role of descending facilitation in neuropathic pain states. In: Emerging strategies for the treatment of neuropathic pain (Campbell JN, Basbaum AI, Dubner R, Dray A, Dworkin RH, Sang CN, eds), pp 211-238. Seattle: IASP.

Ossipov MH, Lai J, Malan Jr TP, Vanderah TW, Porreca F (2001) Tonic descending facilitation as a mechanism of neuropathic pain. In: Neuropathic pain: pathophysiology and treatment (Hansson PT, Fields HL, Hill RG, Marchettini P, eds), pp 107-124. Seattle: IASP.

Ossipov MH, Lai J, Vanderah TW, Porreca F (2003) Induction of pain facilitation by sustained opioid exposure: relationship to opioid antinociceptive tolerance. Life Sci 73:783-800.

Ossipov MH, Lai J, King T, Vanderah TW, Malan Jr TP, Hruby VJ, Porreca F (2004) Antinociceptive and nociceptive actions of opioids. J Neurobiol 61:126-148.

Ossipov MH, Lai J, King T, Vanderah TW, Porreca F (2005) Underlying mechanisms of pronociceptive consequences of prolonged morphine exposure. Biopolymers 80:319-324.

Patrick GN, Bingol B, Weld HA, Schuman EM (2003) Ubiquitin-mediated proteasome activity is required for agonist-induced endocytosis of GluRs. Curr Biol 13:2073-2081.

Saulle E, Petronelli A, Pasquini L, Petrucci E, Mariani G, Biffoni M, Ferretti G, Scambia G, Benedetti-Panici P, Cognetti F, Humphreys R, Peschle C, Testa U (2007) Proteasome inhibitors sensitize ovarian cancer cells to TRAIL induced apoptosis. Apoptosis 12:635-655.

Scadding JW, Koltzenburg M (2005) Painful peripheral neuropathies. In: Wall and Melzack's textbook of pain (McMahon SB, Koltzenburg M, eds), pp 973-1000. London: Elsevier.

Speese SD, Trotta N, Rodesch CK, Aravamudan B, Broadie K (2003) The ubiquitin proteasome system acutely regulates presynaptic protein turnover and synaptic efficacy. Curr Biol 13:899-910.

Tegeder I, Niederberger E, Schmidt R, Kunz S, Gühring H, Ritzeler O, Michaelis M, Geisslinger G (2004) Specific inhibition of I $\kappa$ B kinase reduces hyperalgesia in inflammatory and neuropathic pain models in rats. J Neurosci 24:1637-1645.

Tsubuki S, Saito Y, Tomioka M, Ito H, Kawashima S (1996) Differential inhibition of calpain and proteasome activities by peptidyl aldehydes of di-leucine and tri-leucine. J Biochem (Tokyo) 119:572-576.

Vanderah TW, Laughlin T, Lashbrook JM, Nichols ML, Wilcox GL Ossipov MH, Malan TP, Porreca F (1996) Single intrathecal injections of dynorphin A or des-Tyr-dynorphins produce long-lasting allodynia in rats: blockade by MK-801 but not naloxone. Pain 68:275-281. 
Vanderah TW, Gardell LR, Burgess SE, Ibrahim M, Dogrul A, Zhong CM, Zhang ET, Malan Jr TP, Ossipov MH, Lai J, Porreca F (2000) Dynorphin promotes abnormal pain and spinal opioid antinociceptive tolerance. J Neurosci 20:7074-7079.

Wang Z, Gardell LR, Ossipov MH, Vanderah TW, Brennan MB, Hochgeschwender U, Hruby VJ, Malan Jr TP, Lai J, Porreca F (2001) Pronociceptive actions of dynorphin maintain chronic neuropathic pain. J Neurosci 21:1779-1786.

Wheeler TC, Chin LS, Li Y, Roudabush FL, Li L (2002) Regulation of synaptophysin degradation by mammalian homologues of seven in absentia. J Biol Chem 277:10273-10282.

Willeumier K, Pulst SM, Schweizer FE (2006) Proteasome inhibition triggers activity-dependent increase in the size of the recycling vesicle pool in cultured hippocampal neurons. J Neurosci 26:11333-11341.

Xie W, Liu X, Xuan H, Luo S, Zhao X, Zhou Z, Xu J (2006) Effect of betamethasone on neuropathic pain and cerebral expression of NF-kappaB and cytokines. Neurosci Lett 393:255-259.

Xu M, Petraschka M, McLaughlin JP, Westenbroek RE, Caron MG, Lefkowitz RJ, Czyzyk TA, Pintar JE, Terman GW, Chavkin C (2004) Neuropathic pain activates the endogenous kappa opioid system in mouse spinal cord and induces opioid receptor tolerance. J Neurosci 24:4576-4584.

Yakovleva T, Bazov I, Cebers G, Marinova Z, Hara Y, Ahmed A, Vlaskouska M, Johansson B, Hochgeschwender U, Singh IN, Bruce-Keller AJ, Hurd YL, Kaneko T, Terenius L, Ekstrom TJ, Hauser KF, Pickel VM, Bakalkin G (2006) Prodynorphin storage and processing in axon terminals and dendrites. FASEB J 20:2124-2126.

Yaksh TL, Rudy TA (1976) Chronic catheterization of the spinal subarachnoid space. Physiol Behav 17:1031-1036.

Zhang Q, Tally M, Larsson O, Kennedy RT, Huang L, Hall K, Berggren PO (1997) Insulin-like growth factor II signaling through the insulin-like growth factor II/mannose-6-phosphate receptor promotes exocytosis in insulin-secreting cells. Proc Natl Acad Sci USA 94:6232-6237. 